\title{
Oligodendroglia and Myelin in Neurodegenerative Diseases: More Than Just Bystanders?
}

\author{
Benjamin Ettle ${ }^{1}$. Johannes C. M. Schlachetzki ${ }^{1}$ • Jürgen Winkler ${ }^{1}$
}

Received: 23 February 2015 / Accepted: 29 April 2015 / Published online: 13 May 2015

(C) The Author(s) 2015. This article is published with open access at Springerlink.com

\begin{abstract}
Oligodendrocytes, the myelinating cells of the central nervous system, mediate rapid action potential conduction and provide trophic support for axonal as well as neuronal maintenance. Their progenitor cell population is widely distributed in the adult brain and represents a permanent cellular reservoir for oligodendrocyte replacement and myelin plasticity. The recognition of oligodendrocytes, their progeny, and myelin as contributing factors for the pathogenesis and the progression of neurodegenerative disease has recently evolved shaping our understanding of these disorders. In the present review, we aim to highlight studies on oligodendrocytes and their progenitors in neurodegenerative diseases. We dissect oligodendroglial biology and illustrate evolutionary aspects in regard to their importance for neuronal functionality and maintenance of neuronal circuitries. After covering recent studies on oligodendroglia in different neurodegenerative diseases mainly in view of their function as myelinating cells, we focus on the alpha-synucleinopathy multiple system atrophy, a prototypical disorder with a well-defined oligodendroglial pathology.
\end{abstract}

Keywords Oligodendrocytes $\cdot$ Myelin $\cdot$ Oligodendrocyte progenitor cells $\cdot$ Neurodegenerative diseases $\cdot$ Multiple system atrophy $\cdot$ Alpha-synuclein

Jürgen Winkler

juergen.winkler@uk-erlangen.de

1 Department of Molecular Neurology, Friedrich-Alexander University Erlangen-Nürnberg, Schwabachanlage 6, D-91054 Erlangen, Germany

\section{Introduction}

Age-related neurodegenerative diseases are generally characterized by a progressive axonal and neuronal cell loss within circumscribed or multiple regions of the central nervous system (CNS). Extensive efforts have been undertaken to decipher mechanisms underlying the detrimental cascade during axonal and neuronal degeneration and to exploit avenues to modify disease progression. Although various common neuropathological features including disturbances in protein homeostasis, mitochondrial functionality, and axonal transport have been proposed, the precise mechanisms eventually leading to neuronal dysfunction and death still remain elusive [1-5]. Such a comprehensive understanding, however, is the prerequisite for the development of therapeutic approaches attenuating, halting, or even reversing progressive neurodegeneration. As widespread synaptic and axonal loss ultimately leading to neuronal cell death is the common hallmark of neurodegenerative diseases, research addressing disease causing and modifying factors classically focused on autonomous neuronal mechanisms. However, glial cells, namely astroglia, microglia, and oligodendroglia, move more and more into the focus due to their importance for regulating and maintaining neuronal functionality. Moreover and regardless of the distinct disease examined, studying the involvement of glial cells may complement our understanding of these complex diseases. For instance, neuroinflammatory processes mediated mainly by astrocytes and microglia are observed in almost all neurodegenerative diseases [6]. Furthermore, oligodendrocytes (OLGs) and their widely distributed progenitors profoundly influence and control processes shown to be frequently dysregulated in neurodegenerative diseases including ionic homeostasis and nerve impulse conduction [7-11]. Via their densely packed myelin sheaths, OLGs intimately contact and communicate with axons 
maintaining their integrity as well as regulating axonal and neuronal functionality $[12,13]$. Moreover, OLGs are the only mature cellular phenotype within the adult CNS with an existing, widespread, and proliferative progenitor cell population. These oligodendrocyte progenitor cells (OPCs) are not only implicated in OLG replacement and myelin remodeling, but may also serve as a promising source for neuronal replacement $[14,15]$.

Whereas the literature on oligodendroglial cells in neurodegeneration premillennially comprised only a few studies, the number of reports on this topic has gradually increased over the past few years. Acknowledging the growing evidence of an oligodendroglial contribution to neurodegeneration, the aim of the present review is to highlight recent studies on oligodendroglial cells and their precursors in neurodegenerative disorders. For this purpose, we first reflect on basic aspects of oligodendroglial biology and myelin evolution. Next, we link oligodendroglial and myelin dysfunction to neurodegeneration. Finally, we explicitly dissect the current knowledge on OLGs and their progeny in a distinct neurodegenerative disease by exemplarily considering multiple system atrophy (MSA) as a prototypical entity with a well-known oligodendroglial pathology and even considered to be an oligodendrogliopathy.

\section{Function and Biology of OLGs and Their Progeny}

OLGs represent with $75 \%$ the majority of all glial cells in the adult CNS [16]. The main function of OLGs is the production of myelin, the complex organized and tightly packed enlarged plasma membrane of OLGs wrapped around axons. By insulating axons and clustering sodium channels at myelin-free interspaces - the nodes of Ranvier - myelin enables saltatory action potential conduction. In addition to this well-known function, OLGs have been implicated in various other functions. For instance, OLGs buffer increased extracellular potassium evoked by neuronal excitation, thereby ensuring ionic homeostasis in the CNS [7]. Moreover, OLGs provide metabolic and trophic supply at the axon-myelin unit supporting neurons in maintaining their function $[17,18]$. The provision of lactate as energy source via monocarboxylate transporters is essential for axonal survival. By secretion of growth factors, such as glial- and brain-derived neurotrophic factor (GDNF and BDNF), OLGs not only support axonal functionality, but also modulate axonal outgrowth [19-21]. These examples highlight the importance of OLGs and myelin in preserving neuronal circuitries.

Developmentally, OLGs derive from OPCs arising at the ventricular zone and are detected as early as embryonic day 12.5 in the rodent brain. Upon migration during serial waves toward the CNS, OPCs differentiate and give rise to myelinating OLGs [22]. The sequence of differentiation and myelination is a tightly controlled biological process regulated by extrinsic stimuli and a complex transcriptional network. Extrinsic stimuli promoting OPC differentiation and myelination include hormones (e.g., thyroid hormone [23]), growth factors (e.g., BDNF [24]), cytokines (e.g., interleukin6 [25]), and enzymes (e.g., matrix metalloproteinases [26]). In contrast, several stimuli are described preventing OPC differentiation and myelination, for instance, distinct growth factors (e.g., platelet-derived growth factor (PDGF) [27]) and myelin itself [28]. Transcription factors regulating oligodendroglial differentiation and myelination include amongst others members of the sox family (e.g., sox10 [29]), Olig1 and Olig2 [30], effectors of the Wnt and Notch signaling pathways [31, 32], and the recently identified myelin gene regulatory factor (MYRF) [33].

Although most myelin is produced and laid down during early infancy, OPCs persist in the adult CNS where they are also referred to as NG2 glia (due to their characteristic expression of the neural/glial antigen-2 (NG2)), polydendrocytes, and synantocytes $[15,34]$. OPCs are widely distributed in the adult CNS constituting for up to $9 \%$ of all white matter cells and up to $3 \%$ of all gray matter cells in the rodent brain [35]. Lifelong, OPCs keep their potential to proliferate, migrate, and differentiate into mature, myelinating OLGs. Upon demyelination, OPCs undergo this sequential maturation ultimately leading to remyelination [36-38]. Notably, functional differences regarding the differentiation potential between gray and white matter OPC were recently described as white matter-derived OPCs more rapidly differentiated upon transplantation compared to gray matter-derived OPCs [39]. Interestingly, OPCs not only represent an endogenous source for OLG replacement, but also contribute to CNS plasticity [40]. Recent studies demonstrate that OPCs mediate adaptive myelination and motor skill learning in the adult rodent brain [41, 42]. However, this view on OPCs and myelin plasticity was recently challenged in the human brain by analyzing the integration of nuclear bomb test derived (14)C into human myelin [43]. Referring to this study, myelin remodeling conducted by mature OLGs appears to be the main driver of myelin plasticity in the human brain while OPCs make only a minor contribution. Such discrepancy may be related to a significant difference in oligodendroglial biology between humans and rodents.

It is still controversial, whether OLGs are the sole fate of OPCs [44]. Fate-mapping studies in the adult mouse brain demonstrate a few OPC-derived neurons in addition to newborn OLGs [45-47]. Several other reports, however, argue against the neurogenic potential of OPCs [48-50]. The ability of OPCs to obtain neuronal phenotypes might depend on distinct differences between physiological and diseased microenvironments [44]. Nevertheless, OPCs may serve as cellular reservoir and, thus, as a promising therapeutic target not only for OLG replacement, but also for neuronal regeneration as 
indicated by studies using genetic or pharmaceutical modification to induce the neurogenic potential of OPCs [51, 52]. In addition to their role as progenitors, further regulatory functions have been proposed for OPCs. For instance, it was recently demonstrated that OPCs - synaptically linked to neurons - react activity-dependent to neuronal input with cleavage of the NG2 proteoglycan, thereby modulating the neuronal network [53]. Taken together, OPCs, OLGs, and myelin represent multifunctional constituents essential for the integrity of neuronal circuits. In the following section, we dissect evolutionary and developmental aspects of oligodendroglia and myelin to underline their importance for the extraordinary achievements and the functionality of the human brain.

\section{Evolutionary and Developmental Aspects of Human Myelin}

Undoubtedly, the most important function of OPCs and OLGs is the production of myelin. In fact, myelin represents the most recent crucial step during evolution of the vertebrate CNS appearing first in hinged-jawed placoderms [54]. The rise of myelination is the evolutionary response to the growing size of the vertebrate brain, and thus, it ensures proper neuronal connectivity by facilitating action potential conduction. Myelinated axons require lower currents for signal transduction, and thus, smaller ionic imbalances have to be balanced upon neuronal excitation leading to a major energy economization [55]. Moreover, by accelerating conductivity, myelination is fundamental for the evolution of higher brain functions such as cognition [56]. In addition to myelin, action potential velocity is mainly determined by the axonal diameter. Without the evolution of myelin, axons extraordinary large in diameter would have been required to allow for increasing conductivity. Therefore, spatial optimization is also attributed to myelin [55]. Hence, myelin is an essential factor contributing to the extraordinary accomplishments on neuronal networks in higher organisms such as humans. Considering the fact that neurodegenerative diseases are unique to humanssince not observed in nonhuman primates and other mammals - the development of age-related neurodegenerative diseases may be linked to distinct features of the human brainsuch as myelin. Intriguingly, the complexity and upscaling of the human brain are rather reflected by the exceptionalism of its myelin than by increased neuronal and glial cell numbers. Whereas the gray matter volume proportionally evolved in nonhuman primates and humans, the white matter volume especially in the prefrontal cortex is disproportionally larger in humans $[57,58]$. In fact, myelination correlates not only with the evolution of advanced brain functions, but also with functional brain development and maturation in each individual. For instance, myelination starts around 25 weeks of gestational age and peaks during early infancy, thus coinciding with the rapid cognitive and emotional development during childhood [59-62]. Moreover, neocortical myelination not only more rapidly progresses in the developing human brain, but also protracts far more into the adulthood in humans compared to nonhuman primates at least partly explaining the extraordinary cognitive, emotional, and social achievements linked to the human brain $[63,64]$. Importantly, myelin levels gradually increase until the fifth decade in the human brain before progressively declining in the aging brain as suggested by magnetic resonance imaging (MRI) analyses [65]. As this progressive breakdown of myelin inversely correlates with the increasing risk for the development of neurodegenerative disorders, we next link oligodendroglia/myelin dysfunction to the onset of neurodegeneration.

\section{Oligodendroglial and Myelin Dysfunction: a Link to Neurodegeneration?}

Considering the facts that myelin (i) represents an essential factor for human brain connectivity, (ii) is extraordinarily evolved in humans compared to nonhuman primates and other mammals, and (iii) progressively declines in the aging human brain, oligodendroglial dysfunction significantly contributes to the distinct vulnerability of the human brain for neurodegenerative diseases. Although it is not very likely that myelin dysfunction and oligodendroglial failure are primarily involved in the etiology of neurodegenerative diseases, interindividual variability in OLGs, their progenitors, and/or myelin may define the topographical level of resilience for axonal and neuronal loss. From another point of view, preserved oligodendroglial and myelin functionality may be a crucial prerequisite for the prevention of axonal and neuronal degeneration, e.g., under oxidative or metabolic stress. This causal relationship is supported by several recent studies linking oligodendroglial and myelin dysfunction to axonal and neuronal degeneration.

Strong evidence for an essential contribution of dysmyelination/demyelination to neurodegeneration is derived from studies on multiple sclerosis (MS), one of the best-characterized demyelinating disorders of the CNS [66]. Although the initial MS pathology is tightly linked to autoimmune processes followed by focal demyelination, it is important to note that axonal damage and loss of neuronal integrity represent the structural correlates for the progression of functional deficits in MS patients $[67,68]$. Both in human MS brains and the cuprizone-induced demyelinating model for MS, severe axonal degeneration is observed as a consequence of myelin loss [69, 70]. Intriguingly, while no significant axonal damage is observed in remyelinated shadow plaques, severe axonal degeneration is present in active and inactive demyelinated lesions [71]. This indicates that myelin regeneration supports axonal survival. In line, the group of Nave and 
colleagues demonstrated that the formation of compact myelin is not sufficient for axonal survival. Mice lacking the myelinspecific proteolipid protein 1 assemble physiological myelin sheaths, but develop axonal swellings leading to axonal degeneration. The accumulation of membranous dense bodies and mitochondria within these swellings suggests a profound axonal transport deficiency which may be attributed to the breakdown of the trophic and metabolic support provided by OLGs [72]. Indeed, a more recent study describes pronounced axonal injury upon OLG-specific ablation of monocarboxylate transporters which mediate lactate/pyruvate transport at the myelin-axon junction [18]. These studies in the context of MS highlight the importance of myelin for maintaining axonal integrity and functionality by providing trophic and metabolic support [18, 72, 73].

Furthermore, a notable role was also described for OPCs in MS. Kuhlmann and colleagues observed an accumulation of OPCs in early MS lesions whereas significantly fewer OPC numbers were detected in chronic demyelinated plaques. While Olig2/NogoA double-positive maturating OLGs were present in early lesions, such cells were rarely observed in chronic lesions [74]. Moreover, OLGs which failed to myelinate axons were detected in chronic demyelinated plaques [75]. Considering that axonal damage frequently and predominantly occurs within demyelinated plaques, these findings strongly indicate that a deficiency in both OPC maturation and remyelination contributes to axonal and finally neuronal degeneration in MS [74, 75]. One possible explanation for this self-repair failure is the elevated burden of oxidative and nitrosative stress in MS brains, as these factors were demonstrated to impair OPC maturation [76-78]. In fact, the susceptibility toward oxidative and nitrosative stress is an interesting crosslink between MS and age-related neurodegenerative disease and might act as common denominator in several neurological conditions with white matter alterations $[76$, 77, 79].

Pioneering studies of Bartzokis and colleagues demonstrated a potential link between myelin breakdown and the onset of neurodegenerative diseases including Alzheimer's disease (AD) and Huntington's disease (HD). Using MRI approaches, disturbances of myelin integrity occurring during normal ageing are severely exacerbated in AD and HD [80-82]. Furthermore, increased tissue iron levels - in complex with ferritin which, in turn, is produced in the CNS mainly by oligodendroglia-were measured in AD, HD, and Parkinson's disease (PD) [9, 11, 82, 83]. Altered tissue iron levels increase the concentration of reactive oxygen intermediates [84]. In turn, this provokes changes in the proteins' tertiary structure favoring their aggregation propensities and, eventually, neurodegeneration. Therefore, increased tissue iron is considered as risk factor for the development of neurodegenerative diseases further connecting oligodendroglia to neurodegeneration $[10,85]$. In addition, white matter abnormalities detected by diffusion tensor imaging (DTI) have been proposed as early event in AD and HD [86-88]. In line, amyloid-beta plaque deposition was recently linked to focal demyelination accompanied by a profound oligodendroglial cell loss, suggesting that demyelination contributes to impaired cortical processing in AD [89]. Studies deciphering oligodendroglial pathology in transgenic mouse models support the notion of an oligodendroglial contribution to AD pathogenesis [90, 91]. In this context, Behrendt and colleagues noted an increased proliferation of OPCs in a mouse model of AD [91]. While this observation favors a cellular response to $\mathrm{AD}$ pathology and a potential mechanism for myelin repair, OPC survival, maturation, and myelin sheath formation were negatively influenced by the presence amyloidbeta peptides [92, 93]. Similarly as described in MS, these findings favor a deficiency in remyelination also in AD.

Increased numbers of OPCs indicative for a myelin regeneration failure were also observed in the motor cortex and the spinal cord of amyotrophic lateral sclerosis (ALS) patients, an adult-onset neurodegenerative disease with affection of both the upper and lower motor neuron [94]. Additionally, mice carrying mutations in the SOD1 gene linked to ALS display reactive OPC proliferation upon extensive OLG loss and demyelination even prior to the onset of motor symptoms [49, 94]. The increased number of OPCs was associated with an enhanced differentiation. However, newly generated OLGs exhibited alterations like reduced myelin basic protein (MBP) levels and, thus, were not able to form functional myelin. Indeed, fate-mapping approaches demonstrated that newly formed OLGs were dysmorphic and accumulate with disease progression [95]. Intriguingly, selective ablation of the SOD1 mutation in OPCs and OLGs prolonged survival and delayed disease onset [94]. In line, the ubiquitous reduction of monocarboxylate transporters in OLGs of ALS patients and SOD1 mice implies that the metabolic support of neurons by OLGs is impaired in ALS [18]. These findings indicate an early involvement of oligodendroglia in ALS pathology by increasing neuronal vulnerability.

Taken together, these studies highlight the contribution of myelin dysfunction to neurodegeneration but are, by far, not comprehensive. As the group of neurodegenerative disorders is rather complex and heterogeneous, we next focus on MSA as a neurodegenerative disease with well-known oligodendroglial features.

\section{Oligodendroglial and Myelin Dysfunction in MSA}

\section{Clinic and Epidemiology of MSA}

The term MSA was introduced in the late 1960s combining three initially distinct syndromes: striatonigral degeneration, olivopontocerebellar ataxia, and Shy-Drager syndrome [96]. 
Indeed, considering the broad spectrum of affected systems, MSA patients symptomatically present with a heterogeneous array of autonomic dysfunction, parkinsonism, cerebellar ataxia, and pyramidal features [97]. MSA is a rare neurodegenerative syndrome with a prevalence ranging between 1 and 5 per 100,000. The incidence is highest in the population older than 50 years reaching a maximum of 3 per 100,000/year [98, 99]. Based on a recent multicenter study in Europe, the mean age of onset is 56 years, while the mean survival was estimated to be about 10 years ranging between 2 and 18 [100]. Thus, MSA is a rapidly progressing neurodegenerative disorder, however, with still unknown etiology. Using whole genome sequencing, a recent study conducted in a Japanese cohort of MSA patients identified heterozygous mutations in the COQ2 gene to cause MSA [101]. However, two follow-up studies in China and in the USA did not detect any heterozygous COQ2 mutations $[102,103]$. Nevertheless, common and rare variants of the COQ2 gene were associated with an increased risk for the development of MSA [101-103]. Given these controversial results for the role of the COQ2 locus in MSA, larger cohort studies may help to define the genetic component in MSA. Overall, there is an urgent need for identifying genetic and/or environmental factors underlying MSA pathogenesis, in particular, due to the lack of interventions for MSA patients.

\section{Human Studies on Oligodendroglia and Myelin in MSA}

Neurodegenerative changes in MSA involve predominantly the striatonigral or olivopontocerebellar systems leading to the clinical subtypes MSA-P (with predominant parkinsonism) and MSA-C (with predominant cerebellar features), respectively [104, 105]. In MSA-P, atrophy and gray-greenish discoloration of the putamen as well as loss of pigment from the substantia nigra reflect the involvement of the striatonigral pathway. Atrophy of the cerebellum, pons, and inferior olives is observed in MSA-C brains. Lesions, however, are not restricted to these anatomical regions but involve, in particular, the autonomic nuclei within the spinal cord and brain stem reflecting the broad spectrum of autonomic dysfunction observed in MSA [106]. The neurodegenerative changes are accompanied by white matter abnormalities in the aforementioned anatomical regions. Reduced myelin staining and MBP protein levels were detected [107, 108]. Furthermore, patches of degraded myelin were reported [109]. It is noteworthy to point out that white matter changes are readily detected in MSA patients during lifetime by employing DTI $[110,111]$. Specifically, white matter abnormalities were detected in the putamen and middle cerebellar peduncles [112-115].

In 1989, Papp and Lantos described the accumulation of insoluble glial cytoplasmic inclusions (GCIs) as the pathological hallmark of MSA. GCIs were primarily observed within mature OLGs and were thus suggested to be causal for the widespread myelin loss associated with both axonal and neuronal degeneration in MSA $[108,116]$. Notably, the vast myelin loss observed in MSA patients is not accompanied by a severe loss in numbers of mature OLGs [117]. Alterations in the glial compartment within the white matter, however, are not restricted to oligodendroglial cells but include astrocytes and microglia. For instance, the extent of reactive astrocytosis parallels the degree of neurodegeneration in the striatonigral and olivopontocerebellar projections [104, 118, 119]. Furthermore, activated microglia phagocytosing myelin are detected within the white matter tracts and are closely associated with the distribution of GCIs [120]. Neuronal cytoplasmic inclusions (NCIs) and neuronal nuclear inclusions (NNIs) are also present in MSA, however, less frequently as GCIs [121]. After revealing GCIs in oligodendroglial cells as defining neuropathological feature of MSA, Papp and Lantos linked the regional GCI pattern to neurological deficits in MSA patients, suggesting that GCI formation in OLGs is rather early and causally involved in MSA pathogenesis [122, 123]. Further support for the pivotal role of GCIs in the pathogenesis of MSA is derived from the correlation of the anatomical distribution between GCIs and neurodegeneration [104, 124, 125]. Moreover, GCI load increases with disease progression [104, 122, 125].

Three almost simultaneously published studies 10 years after the initial description of GCIs revealed alpha-synuclein as the main proteinaceous constituent of GCIs [126-128]. MSA shares the aggregation of alpha-synuclein as a major pathological hallmark with PD and dementia with Lewy bodies (DLB) leading to the classification of these diseases as synucleinopathies [129]. Several additional proteinaceous components of GCIs were defined (for an overview, see Table 1); alpha-synuclein oligomers and fibrils, however, form the central core of GCIs [152]. The group of Jensen and colleagues described disturbances in the interaction between p25-alpha and one of the major myelin proteins, MBP, in the brains of MSA patients as an early event during GCI formation [109]. P25-alpha, also known as tubulin polymerization-promoting protein due to its microtubulebinding activity, is an OLG-specific phosphoprotein. Although its exact function in the myelin sheath is still unknown, p25-alpha expression begins along with MBP and is thus considered as a marker for myelinating OLGs. An ubiquitous cytoplasmic relocalization of p25-alpha which usually strongly interacts with MBP in the myelin sheath was detected. Concomitantly, MBP protein levels severely decreased, indicating that $\mathrm{p} 25$-alpha redistribution induces demyelination. In addition, p25-alpha was shown to induce alphasynuclein aggregation and GCI formation [109, 153, 154].

Additional studies investigating OLG and myelin functionality support the notion of an early oligodendroglial and myelin involvement in MSA. Alterations in the lipid composition restricted to affected regions in MSA brains were recently reported [155]. In line, increased expression of the ATPbinding cassette transporter 8 (ABCA8) involved in lipid 
Table 1 Overview of proteins and their major function identified as components of glial cytoplasmic inclusions in multiple system atrophy

\begin{tabular}{|c|c|c|}
\hline Protein & Main function/cellular process & Reference \\
\hline Alpha-synuclein & Presynaptic vesicle release & {$[126]$} \\
\hline Cyclin-dependent kinase 5 (CDK5) & Cell cycle regulation & {$[130]$} \\
\hline Mitogen-activated protein kinase (MAPK) & Signal transduction & {$[130]$} \\
\hline Midkine & Neurotrophic factor & {$[131]$} \\
\hline Rab5 & Endocytosis regulation & [132] \\
\hline Rabaptin-5 & Endocytosis regulation & {$[132]$} \\
\hline P39 & CDK5 activator & [133] \\
\hline Elk1 & Transcription factor & {$[134]$} \\
\hline Tau & Microtubule associated protein & [135] \\
\hline 14-3-3 proteins & Signal transduction & [136] \\
\hline Clusterin/apolipoprotein J & Several functions incl. apoptosis & {$[137]$} \\
\hline Synphilin-1 & Alpha-synuclein interacting protein (SNCAIP) & [138] \\
\hline Dorfin & Protein degradation & [139] \\
\hline Small ubiquitin-like modifier (SUMO-1) & Protein degradation & {$[140]$} \\
\hline Alpha B-crystallin & Protein folding & [141] \\
\hline $\begin{array}{l}\text { Negative regulator of ubiquitin-like } \\
\text { proteins } 1 \text { (NUB-1) }\end{array}$ & Negative regulation of NEDD8 & [142] \\
\hline Parkin co-regulated gene (PACRG) & Regulation of cell death & [143] \\
\hline P25-alpha & Tubulin polymerization & [109] \\
\hline DARPP32 & Regulation of signal transduction & [144] \\
\hline HtrA2/Omi & Apoptosis & [145] \\
\hline Protein disulfide isomerase (PDI) & Protein folding & [146] \\
\hline Metallothionein-III & Metal binding & {$[147]$} \\
\hline $\begin{array}{l}\text { Gamma-tubulin } \\
\text { Histone deacetylase } 6 \text { (HDAC6) }\end{array}$ & $\begin{array}{l}\text { Microtubule nucleation } \\
\text { Tubulin deacetylation }\end{array}$ & [148] \\
\hline 20S proteasome subunits & Protein degradation & \\
\hline Heat shock protein $70(\mathrm{Hsp} 70)$ & Protein folding & \\
\hline Heat shock protein 90 (Hsp90) & Protein folding & \\
\hline 62-kDa protein/sequestosome 1 (p62/SQSTM1) & Autophagy & \\
\hline NBR1 & Autophagy & [149] \\
\hline F-box only protein 7 (FBXO7) & Ubiquitination & {$[150]$} \\
\hline $\mathrm{X}$-linked inhibitor of apoptosis protein (XIAP) & Regulation of apoptosis & {$[151]$} \\
\hline
\end{tabular}

transportation in OLGs of MSA patients favors a pivotal oligodendroglial dysfunction in MSA as overexpression of ABCA8 elevates alpha-synuclein and p25-alpha expression [156]. Moreover, GCI-negative OLGs already display increased activity of the endoplasmatic reticulum-associated unfolded protein response [157]. The demonstration of altered oligodendroglial nuclei in absence of GCIs further indicates a general oligodendroglial dysfunction preceding alphasynuclein aggregation and GCI formation. However, most research focused on the pathogenic role of alpha-synuclein in OLGs during MSA progression [158].

Biochemical and histological studies characterized modifications and solubility of alpha-synuclein demonstrating its abundant alterations in the brains of MSA patients [159-163]. For instance, the accumulation of nitrated alphasynuclein is observed in MSA, PD, and DLB, and thus, oxidative modifications of alpha-synuclein appear to be common in synucleinopathies [163]. Several groups aimed to decipher the origin of abnormal alpha-synuclein accumulation in OLGs of MSA patients. It is still a matter of debate whether alphasynuclein is pathologically overexpressed or taken up by OLGs in MSA. Whereas some studies imply the absence of elevated alpha-expression expression, various other reports argue for an elevated alpha-synuclein expression in OLGs of MSA patients [164-168]. It is important to note that mutations or multiplications of alpha-synuclein gene are not detected in MSA patients [169-171]. Polymorphisms within the alphasynuclein locus, however, are commonly observed in MSA patients possibly explaining altered expression of alphasynuclein in OLGs of MSA patients [172, 173]. This controversy is supported by studies in animal and cell culture models providing explanations for both the exogenous and the endogenous origin of alpha-synuclein within OLGs of MSA patients [174-181]. Considering these studies, it is reasonable to 
hypothesize that both autonomously expressed and taken up alpha-synucleins contribute to the cellular phenotype observed in MSA brains.

Although representing a potential cellular source for OLG replacement, studies on OPCs in MSA patients are rare. Two studies recently reported increased numbers of OPCs in MSA patients $[182,183]$. May and colleagues additionally demonstrated the presence of alpha-synuclein accumulation within a small number of striatal OPCs [183]. Thus, alpha-synuclein accumulation within precursor cells may disrupt OLG replacement and myelin regeneration contributing to the profound myelin loss observed in MSA. Summarizing the spectrum of imaging and postmortem studies conducted in MSA patients, oligodendroglial and myelin dysfunction is a general feature occurring early during pathogenesis or even being causal for MSA.

\section{Preclinical Studies on Oligodendroglia and Myelin in MSA}

Because aggregated alpha-synuclein is the major constituent of GCIs, generation of preclinical in vivo and in vitro MSA models targets alpha-synuclein expression. Until now, three transgenic mouse lines have been generated, in which alphasynuclein overexpression in mature OLGs is achieved by driving expression under the control of different myelin gene promoters, namely the 2',3'-cyclic-nucleotide-phosphodiesterase (CNP) [184], the proteolipid protein (PLP) [185], and the MBP promoter [186]. Independent of the promoter used for oligodendroglial alpha-synuclein expression, typical pathological hallmarks observed in MSA patients including motor impairment and profound myelin loss are recapitulated in all three models [184-186]. Dopaminergic cell loss in the substantia nigra is observed in PLP and MBP mice, while MBP-driven alpha-synuclein expression additionally leads to a reduction of striatal neurons and tyrosine-hydroxylasepositive fibers [185-187]. In contrast to motor dysfunction, nonmotor symptoms including impaired olfaction as well as cardiovascular and urogenital dysfunction are less mirrored in transgenic mice [188-192]. In the PLP-driven model, however, oligodendroglial lesions and neuronal cell loss were recently described in multiple regions controlling autonomic functions matching the occurrence of cardiovascular dysfunctions in this model [189, 193].

The presence of axonal and neuronal cell loss, albeit being far more moderate than observed in MSA patients, as well as similarities to the neurological phenotype in oligodendroglial alpha-synuclein mice, strengthens the view on a causal role of oligodendroglia in MSA pathogenesis. Demonstrated in the CNP model, oligodendroglial alpha-synucleinopathy also induces neuronal alpha-synuclein aggregation by release of the secretory protein cystatin $\mathrm{C}$ and, thus, potentially triggers neurodegeneration in a direct manner [194]. Additional evidences for a pivotal role of alpha-synuclein in MSA etiology are derived from distinct mouse lines expressing different levels of alpha-synuclein under the control of the MBP promoter. With increasing levels of alpha-synuclein overexpression, the degree of myelin loss and striatal fiber integrity aggravates. A high level of alpha-synuclein overexpression even causes premature death of transgenic mice resembling the fast disease progression in MSA patients [186]. The involvement of OPCs in MSA is also recapitulated in the MBP model as increased numbers of newborn OPCs were recently described [183]. In this study, the increased number of OPCs was concomitant with a severe myelin loss. Since the numbers of mature OLGs were not altered, this observation suggests a maturation deficit of OPCs preventing OLG replacement and remyelination.

Several studies additionally triggered oligodendroglial dysfunction in transgenic mice overexpressing alpha-synuclein. In order to analyze the contribution of proteolytic failure to oligodendroglia linked pathology in MSA, Stefanova and colleagues systemically inhibited proteasomal activity in PLPdriven alpha-synuclein transgenic mice. Triggered by increased proteolytic stress, oligodendroglial alpha-synuclein accumulation was enhanced, and myelin dysfunction and neuronal cell death associated with an altered motor phenotype were detected supporting the increased vulnerability of OLGs in MSA [195]. An early involvement of proteolytic failure in OLGs during MSA pathogenesis is further supported by in vitro evidences for altered autophagic and proteasomal functionality in OLGs upon alpha-synuclein expression [196]. In line, by enhancing oxidative modifications of alpha-synuclein using the mitochondrial inhibitor 3nitropropionic acid (3NP), neuropathology and neurological deficits exacerbated in both the PLP- and the MBP-driven transgenic MSA model implying increased susceptibility of alpha-synuclein-bearing OLGs toward oxidative stress [187, 197]. In cultured OLGs, alpha-synuclein aggregation was promoted under oxidative conditions, while increased intracellular alpha-synuclein per se exerted no toxic effect [198-201]. In line, OLG overexpressing alpha-synuclein only underwent apoptosis when co-expression of p25-alpha triggered alphasynuclein aggregation [202, 203]. Sole overexpression of alpha-synuclein does not promote apoptosis during differentiation of cultured OPC [174]. Additionally, reduced production of reactive oxygen species using selective inhibition of the myeloperoxidase resulted in a profound attenuation of alpha-synuclein pathology, motor impairment, and neurodegeneration [204]. Interestingly, while 3NP injections in wildtype mice caused neuropathological alterations mimicking MSA pathology, alpha-synuclein knockout mice were resilient toward 3NP-induced pathology [205, 206]. These studies imply that alpha-synuclein accumulation and oxidative stress are concomitantly involved in MSA pathogenesis. The selective vulnerability of oligodendroglial cells toward oxidative stress may be partially explained by their extraordinary metabolic requirements for myelin maintenance [207]. 
Ubhi and colleagues aimed to decipher the contribution of neurotrophic support provided by OLGs for neurodegeneration in the MBP model for MSA. A specific reduction in oligodendroglial-derived GDNF levels was described in MBP mice, while BDNF and insulin-like growth factor-1 levels were similarly reduced in mice expressing alphasynuclein under neuronal promoters. Restoration of GDNF levels either upon intracerebroventricular infusion or mediated by fluoxetine administration attenuated neurodegeneration, suggesting that reduced trophic support by OLGs significantly contributes to axonal and, ultimately, neuronal degeneration in MSA [208, 209].

Despite the recognition of distinct pathological aspects linked to alpha-synuclein and OLGs in MSA as well as the generation of preclinical models suitable for testing therapeutic interventions, modeling MSA-like pathology by using myelin gene promoter-driven alpha-synuclein expression bears certain limitations. As the currently used MSA mouse models constitutively express human alpha-synuclein, developmentally expressed alpha-synuclein may profoundly contribute to the pathology observed in transgenic mice limiting the validity of interpretations drawn in such studies. Supporting this view, alpha-synuclein is transiently upregulated during development of cultured OLGs [180]. Moreover, two recent studies highlight the detrimental impact of intracellular alpha-synuclein on OPC maturation [174, 183]. In two independent cell culture models, alpha-synuclein overexpression dramatically impaired the maturation of the OPC-like central glia-4 (CG4) cell line and primary rat-derived OPCs demonstrated by reduced upregulation of MBP protein during maturation. Decreasing the level of intracellular alpha-synuclein, however, restored the maturation potential of primary OPCs indicating a tight link between alpha-synuclein and OPC differentiation [174]. Given this interference of alpha-synuclein with OPC maturation, it would be important to establish transgenic mouse lines conditionally expressing alpha-synuclein in order to better model MSA as an age-related neurodegenerative disorder. In fact, the observation of increased OPC numbers, the presence of alpha-synuclein accumulation within a subset of striatal OPCs in MSA patients, and the interference of alpha-synuclein with OPC maturation suggest that not only mature OLGs are affected in MSA demanding the generation of transgenic models expressing alphasynuclein controlled by more immature oligodendroglial promoters, e.g., PDGF receptor alpha [174, 182, 183].

Table 2 Pathological alterations detected in or associated with (A) oligodendrocyte progenitor cells, (B) oligodendrocytes, and (C) myelin in multiple system atrophy and its preclinical models

\begin{tabular}{|c|c|c|}
\hline A. Oligodendrocyte progenitor cells (OPCs) & System/tissue & Reference \\
\hline Alpha-synuclein accumulation in OPCs & Human: postmortem & [183] \\
\hline \multirow[t]{2}{*}{ Increased numbers of OPCs } & Human: postmortem & {$[182,183]$} \\
\hline & In vivo: MBP model & {$[183]$} \\
\hline Impaired maturation of alpha-synuclein-expressing OPCs & In vitro: primary and permanent cells & {$[174,183]$} \\
\hline B. Oligodendrocytes (OLGs) & System/tissue & Reference \\
\hline GCIs & Human: postmortem & {$[66,108,116]$} \\
\hline Alpha-synuclein as major GCI component & Human: postmortem & {$[126-128,152]$} \\
\hline Modification and insolubility of alpha-synuclein & Human: postmortem & {$[159-163]$} \\
\hline Correlation between GCIs distribution and neurodegeneration & Human: postmortem & {$[104,122-125]$} \\
\hline \multirow[t]{2}{*}{ Moderate loss of OLGs } & Human: postmortem & {$[117]$} \\
\hline & In vivo: CNP and PLP models & {$[184,193,195]$} \\
\hline Increased activity of unfolded protein response & Human: postmortem & {$[157]$} \\
\hline Altered morphology of oligodendroglial nuclei & Human: postmortem & {$[158]$} \\
\hline Autophagic and proteasomal dysfunction & In vitro: primary cells & [196] \\
\hline Increased vulnerability toward proteolytic stress & In vivo: PLP model & [195] \\
\hline \multirow[t]{2}{*}{ Increased vulnerability toward oxidative stress } & In vivo: MBP and PLP models & {$[192,197,204-206]$} \\
\hline & In vitro: primary and permanent cells & [198-201] \\
\hline Reduced neurotrophic support & In vivo: MBP model & {$[208,209]$} \\
\hline C. Myelin & System/tissue & Reference \\
\hline \multirow[t]{2}{*}{ Myelin loss } & Human: postmortem, diffusion tensor imaging & {$[107-115]$} \\
\hline & In vivo: MBP, and CNP, PLP models & {$[183,184,186,195]$} \\
\hline Altered lipid composition & Human: postmortem & {$[155]$} \\
\hline Altered expression of lipid transport proteins & Human: postmortem & {$[156]$} \\
\hline Protein redistribution & Human: postmortem & [109] \\
\hline
\end{tabular}




\section{Impact of Oligodendroglial and Myelin Dysfunction for MSA Etiology and Progression}

Our current concept on MSA pathogenesis mainly derives from human studies using postmortem brain tissue and preclinical in vitro and in vivo approaches modeling MSA using forced alpha-synuclein expression. The collection of the aforementioned studies (for an overview, see Table 2) shaped our view on MSA assuming a primary oligodendrogliopathy underlying MSA etiology and progression [210]. While conclusions drawn after postmortem analyses in human brains are usually limited to observations on end-stage MSA pathology, experimental models help us to better understand distinct aspects of disease pathogenesis. The pathological sequence illustrated in Fig. 1 summarizes clinical and preclinical data discussed in the present review. Nevertheless, this detrimental cascade described below is still incomplete and may be speculative to some extent.

Compared to healthy controls (Fig. 1a), MSA brains are characterized by a profound myelin and neuronal cell loss accompanied by a severe inflammation such as widespread astrogliosis and microgliosis (Fig. 1d) [117, 211]. Additionally, OPCs contribute to MSA pathology as recent studies demonstrate the presence of alpha-synuclein accumulation within OPCs and increased OPC numbers in MSA patients. Experimental evidences suggest that OLGs are dysfunctional early or even initially during MSA pathogenesis (Fig. 1b). This dysfunction may be related to an increased vulnerability of OLGs toward environmental factors (for example, oxidative and proteolytic stress) due to a distinct genetic predisposition. Subsequently, disturbed protein homeostasis within OLGs leads to myelin dysintegrity and the formation of insoluble GCIs consisting mainly of aggregated alpha-synuclein causing demyelination. Neuroinflammation was observed as a consequence of alpha-synuclein overexpression and OLG/myelin dysfunction in MSA mouse models (Fig. 1c) [186, 212, 213]. Triggered by these inflammatory processes and the recently described deficiency in OPC maturation and putatively in remyelination, OLG dysfunction and myelin loss lead to axonal and neuronal degeneration representing the ultimate pathological correlate for the severe clinical phenotype observed in MSA patients.

\section{Concluding Remarks}

In the present review, we highlight the growing understanding on OPCs and OLGs in the context of neurodegenerative diseases. In concert with other glial cells, the contribution of OLGs and their progeny to the widespread axonal and neuronal degeneration is more and more recognized. We aimed to illustrate that oligodendroglial dysfunction is observed in several neurodegenerative diseases, however, being extraordinary in MSA. In this synucleinopathy characterized by its fast and deleterious disease course, the importance of OPCs, OLGs, and myelin for maintaining and supporting neuronal

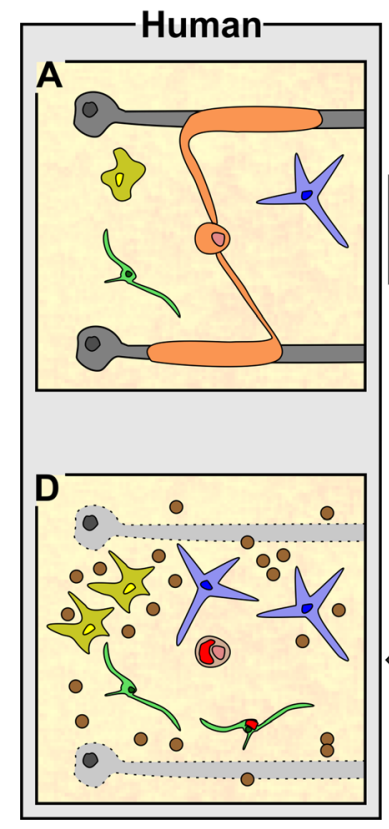

Fig. 1 Schematic illustration of the putative pathological sequence underlying MSA pathogenesis. a The cellular composition of the healthy human central nervous system is depicted. b Dysfunction of myelinating oligodendrocytes with subsequent alpha-synuclein aggregation and glial cytoplasmic inclusion formation is considered as the primary pathological event in MSA. c Oligodendrocytic dysfunction

\section{Models}
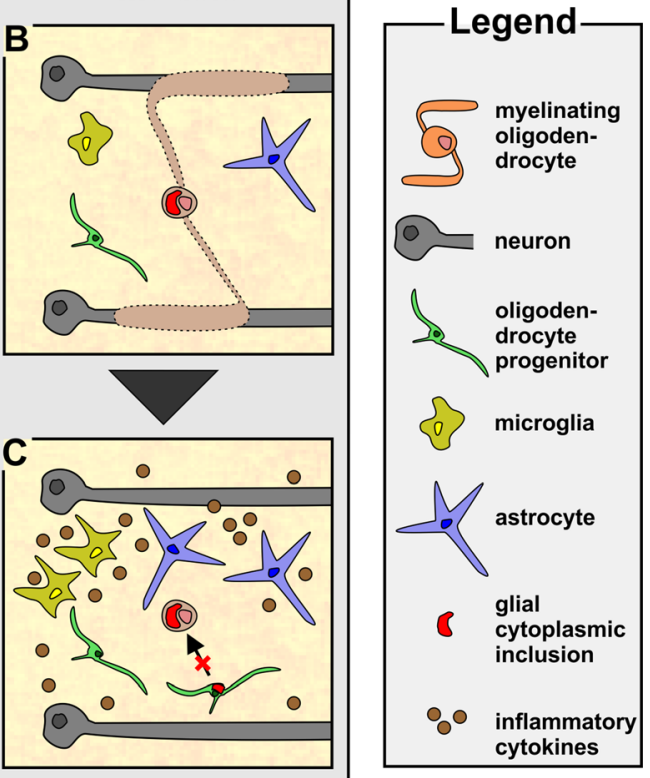

and myelin loss induce reactive microgliosis and astrogliosis mediating neuroinflammatory processes. Alpha-synuclein accumulation is also observed in oligodendrocyte progenitors preventing replacement of dysfunctional oligodendrocytes. d Ultimately, severe axonal and neuronal degeneration is observed in the central nervous system of endstage MSA patients 
circuitries is evident. Thus, MSA represents a model disease as well as a platform to study the detrimental consequences of oligodendroglial failure for neuronal functionality and survival. Future studies addressing the pathophysiology of OPCs/OLGs and myelin in different neurodegenerative disorders will broaden our understanding of these diseases and potentially open novel avenues for interventional strategies. As OLGs are the only adult cell population with a widespread and proliferative progenitor population, promoting OLG replacement and remyelination may be a promising therapeutic target. In similarity to the extensive efforts already undertaken in the context of MS, enhancing OLG and myelin regeneration in MSA and other neurodegenerative diseases including $\mathrm{AD}$ and ALS may support axonal and neuronal maintenance and, thus, attenuate or even halt disease progression.

Acknowledgments This work is supported by the Interdisciplinary Center for Clinical Research (IZKF, TP E18: "Assessing developmental potential and differentiation capabilities of NG2-positive cells in the healthy and diseased central nervous system"). B.E. is an IZKF PhD student and recipient of an IZKF fellowship.

\section{Compliance with Ethical Standards}

Conflict of Interest The authors declare that they have no conflict of interest.

Open Access This article is distributed under the terms of the Creative Commons Attribution 4.0 International License (http:// creativecommons.org/licenses/by/4.0/), which permits unrestricted use, distribution, and reproduction in any medium, provided you give appropriate credit to the original author(s) and the source, provide a link to the Creative Commons license, and indicate if changes were made.

\section{References}

1. Prots I, Veber V, Brey S, Campioni S, Buder K, Riek R, Bohm KJ, Winner B (2013) alpha-Synuclein oligomers impair neuronal microtubule-kinesin interplay. J Biol Chem 288(30):2174221754. doi:10.1074/jbc.M113.451815

2. Millecamps S, Julien JP (2013) Axonal transport deficits and neurodegenerative diseases. Nat Rev Neurosci 14(3):161-176. doi: $10.1038 / \mathrm{nrn} 3380$

3. Itoh K, Nakamura K, Iijima M, Sesaki H (2013) Mitochondrial dynamics in neurodegeneration. Trends Cell Biol 23(2):64-71. doi:10.1016/j.tcb.2012.10.006

4. Klucken J, Poehler AM, Ebrahimi-Fakhari D, Schneider J, Nuber S, Rockenstein E, Schlotzer-Schrehardt U, Hyman BT et al (2012) Alpha-synuclein aggregation involves a bafilomycin A 1-sensitive autophagy pathway. Autophagy 8(5):754-766. doi:10.4161/auto. 19371

5. Dantuma NP, Bott LC (2014) The ubiquitin-proteasome system in neurodegenerative diseases: precipitating factor, yet part of the solution. Front Mol Neurosci 7:70. doi:10.3389/fnmol.2014. 00070

6. Heneka MT, Kummer MP, Latz E (2014) Innate immune activation in neurodegenerative disease. Nat Rev Immunol 14(7):463477. doi:10.1038/nri3705
7. Menichella DM, Majdan M, Awatramani R, Goodenough DA, Sirkowski E, Scherer SS, Paul DL (2006) Genetic and physiological evidence that oligodendrocyte gap junctions contribute to spatial buffering of potassium released during neuronal activity. $\mathrm{J}$ Neurosci Off J Soc Neurosci 26(43):10984-10991. doi:10.1523/ JNEUROSCI.0304-06.2006

8. Iwata NK, Aoki S, Okabe S, Arai N, Terao Y, Kwak S, Abe O, Kanazawa I et al (2008) Evaluation of corticospinal tracts in ALS with diffusion tensor MRI and brainstem stimulation. Neurology 70(7):528-532. doi:10.1212/01.wnl.0000299186.72374.19

9. Todorich B, Pasquini JM, Garcia CI, Paez PM, Connor JR (2009) Oligodendrocytes and myelination: the role of iron. Glia 57(5): 467-478. doi:10.1002/glia.20784

10. Ward RJ, Zucca FA, Duyn JH, Crichton RR, Zecca L (2014) The role of iron in brain ageing and neurodegenerative disorders. Lancet Neurol 13(10):1045-1060. doi:10.1016/S1474-4422(14)70117-6

11. Bartzokis G, Tishler TA, Shin IS, Lu PH, Cummings JL (2004) Brain ferritin iron as a risk factor for age at onset in neurodegenerative diseases. Ann N Y Acad Sci 1012:224-236

12. Funfschilling U, Supplie LM, Mahad D, Boretius S, Saab AS, Edgar J, Brinkmann BG, Kassmann CM et al (2012) Glycolytic oligodendrocytes maintain myelin and long-term axonal integrity. Nature 485(7399):517-521. doi:10.1038/nature11007

13. Fruhbeis C, Frohlich D, Kuo WP, Amphornrat J, Thilemann S, Saab AS, Kirchhoff F, Mobius W et al (2013) Neurotransmittertriggered transfer of exosomes mediates oligodendrocyte-neuron communication. PLoS Biol 11(7):e1001604. doi:10.1371/journal. pbio. 1001604

14. Crawford AH, Stockley JH, Tripathi RB, Richardson WD, Franklin RJ (2014) Oligodendrocyte progenitors: adult stem cells of the central nervous system? Exp Neurol 260:50-55. doi:10. 1016/j.expneurol.2014.04.027

15. Nishiyama A, Komitova M, Suzuki R, Zhu X (2009) Polydendrocytes (NG2 cells): multifunctional cells with lineage plasticity. Nat Rev Neurosci 10(1):9-22. doi:10.1038/nrn2495

16. Pelvig DP, Pakkenberg H, Stark AK, Pakkenberg B (2008) Neocortical glial cell numbers in human brains. Neurobiol Aging 29(11):1754-1762. doi:10.1016/j.neurobiolaging.2007.04.013

17. Beirowski B (2013) Concepts for regulation of axon integrity by enwrapping glia. Front Cell Neurosci 7:256. doi:10.3389/fncel. 2013.00256

18. Lee Y, Morrison BM, Li Y, Lengacher S, Farah MH, Hoffman PN, Liu Y, Tsingalia A et al (2012) Oligodendroglia metabolically support axons and contribute to neurodegeneration. Nature 487(7408):443-448. doi:10.1038/nature11314

19. Wilkins A, Majed H, Layfield R, Compston A, Chandran S (2003) Oligodendrocytes promote neuronal survival and axonal length by distinct intracellular mechanisms: a novel role for oligodendrocyte-derived glial cell line-derived neurotrophic factor. J Neurosci Off J Soc Neurosci 23(12):4967-4974

20. Du Y, Dreyfus CF (2002) Oligodendrocytes as providers of growth factors. J Neurosci Res 68(6):647-654. doi:10.1002/jnr.10245

21. Dai X, Lercher LD, Clinton PM, Du Y, Livingston DL, Vieira C, Yang L, Shen MM et al (2003) The trophic role of oligodendrocytes in the basal forebrain. J Neurosci Off J Soc Neurosci 23(13): 5846-5853

22. Richardson WD, Kessaris N, Pringle N (2006) Oligodendrocyte wars. Nat Rev Neurosci 7(1):11-18. doi:10.1038/nrn1826

23. Calza L, Fernandez M, Giuliani A, Aloe L, Giardino L (2002) Thyroid hormone activates oligodendrocyte precursors and increases a myelin-forming protein and NGF content in the spinal cord during experimental allergic encephalomyelitis. Proc Natl Acad Sci U S A 99(5):3258-3263. doi:10.1073/pnas.052704499

24. McTigue DM, Horner PJ, Stokes BT, Gage FH (1998) Neurotrophin-3 and brain-derived neurotrophic factor induce oligodendrocyte proliferation and myelination of regenerating axons 
in the contused adult rat spinal cord. J Neurosci Off J Soc Neurosci 18(14):5354-5365

25. Valerio A, Ferrario M, Dreano M, Garotta G, Spano P, Pizzi M (2002) Soluble interleukin-6 (IL-6) receptor/IL-6 fusion protein enhances in vitro differentiation of purified rat oligodendroglial lineage cells. Mol Cell Neurosci 21(4):602-615

26. Larsen PH, DaSilva AG, Conant K, Yong VW (2006) Myelin formation during development of the CNS is delayed in matrix metalloproteinase-9 and -12 null mice. J Neurosci Off J Soc Neurosci 26(8):2207-2214. doi:10.1523/JNEUROSCI.1880-05.2006

27. Noble M, Murray K, Stroobant P, Waterfield MD, Riddle P (1988) Platelet-derived growth factor promotes division and motility and inhibits premature differentiation of the oligodendrocyte/type-2 astrocyte progenitor cell. Nature 333(6173):560-562. doi:10. 1038/333560a0

28. Kotter MR, Li WW, Zhao C, Franklin RJ (2006) Myelin impairs CNS remyelination by inhibiting oligodendrocyte precursor cell differentiation. J Neurosci Off J Soc Neurosci 26(1):328-332. doi: 10.1523/JNEUROSCI.2615-05.2006

29. Stolt CC, Rehberg S, Ader M, Lommes P, Riethmacher D, Schachner M, Bartsch U, Wegner M (2002) Terminal differentiation of myelinforming oligodendrocytes depends on the transcription factor Sox10. Genes Dev 16(2):165-170. doi:10.1101/gad.215802

30. Meijer DH, Kane MF, Mehta S, Liu H, Harrington E, Taylor CM, Stiles CD, Rowitch DH (2012) Separated at birth? The functional and molecular divergence of OLIG1 and OLIG2. Nat Rev Neurosci 13(12):819-831. doi:10.1038/nrn3386

31. Fancy SP, Baranzini SE, Zhao C, Yuk DI, Irvine KA, Kaing S, Sanai N, Franklin RJ et al (2009) Dysregulation of the Wnt pathway inhibits timely myelination and remyelination in the mammalian CNS. Genes Dev 23(13):1571-1585. doi:10.1101/gad.1806309

32. Wang S, Sdrulla AD, diSibio G, Bush G, Nofziger D, Hicks C, Weinmaster G, Barres BA (1998) Notch receptor activation inhibits oligodendrocyte differentiation. Neuron 21(1):63-75

33. Emery B, Agalliu D, Cahoy JD, Watkins TA, Dugas JC, Mulinyawe SB, Ibrahim A, Ligon KL et al (2009) Myelin gene regulatory factor is a critical transcriptional regulator required for CNS myelination. Cell 138(1):172-185. doi:10.1016/j.cell.2009.04.031

34. Nishiyama A, Watanabe M, Yang Z, Bu J (2002) Identity, distribution, and development of polydendrocytes: NG2-expressing glial cells. J Neurocytol 31(6-7):437-455

35. Dawson MR, Polito A, Levine JM, Reynolds R (2003) NG2expressing glial progenitor cells: an abundant and widespread population of cycling cells in the adult rat CNS. Mol Cell Neurosci 24(2):476-488

36. Franklin RJ, Ffrench-Constant C (2008) Remyelination in the CNS: from biology to therapy. Nat Rev Neurosci 9(11):839855. doi: $10.1038 / \mathrm{nrn} 2480$

37. Smith KJ, Blakemore WF, McDonald WI (1979) Central remyelination restores secure conduction. Nature 280(5721): 395-396

38. Groves AK, Barnett SC, Franklin RJ, Crang AJ, Mayer M, Blakemore WF, Noble M (1993) Repair of demyelinated lesions by transplantation of purified O-2A progenitor cells. Nature 362(6419):453-455. doi:10.1038/362453a0

39. Vigano F, Mobius W, Gotz M, Dimou L (2013) Transplantation reveals regional differences in oligodendrocyte differentiation in the adult brain. Nat Neurosci 16(10):1370-1372. doi:10.1038/nn.3503

40. Young KM, Psachoulia K, Tripathi RB, Dunn SJ, Cossell L, Attwell D, Tohyama K, Richardson WD (2013) Oligodendrocyte dynamics in the healthy adult CNS: evidence for myelin remodeling. Neuron 77(5):873-885. doi:10.1016/j. neuron.2013.01.006

41. Gibson EM, Purger D, Mount CW, Goldstein AK, Lin GL, Wood LS, Inema I, Miller SE et al (2014) Neuronal activity promotes oligodendrogenesis and adaptive myelination in the mammalian brain. Science 344(6183):1252304. doi:10.1126/science.1252304

42. McKenzie IA, Ohayon D, Li H, de Faria JP, Emery B, Tohyama K, Richardson WD (2014) Motor skill learning requires active central myelination. Science 346(6207):318-322. doi:10.1126/science. 1254960

43. Yeung MS, Zdunek S, Bergmann O, Bernard S, Salehpour M, Alkass K, Perl S, Tisdale J et al (2014) Dynamics of oligodendrocyte generation and myelination in the human brain. Cell 159(4): 766-774. doi:10.1016/j.cell.2014.10.011

44. Richardson WD, Young KM, Tripathi RB, McKenzie I (2011) NG2-glia as multipotent neural stem cells: fact or fantasy? Neuron 70(4):661-673. doi:10.1016/j.neuron.2011.05.013

45. Rivers LE, Young KM, Rizzi M, Jamen F, Psachoulia K, Wade A, Kessaris N, Richardson WD (2008) PDGFRA/NG2 glia generate myelinating oligodendrocytes and piriform projection neurons in adult mice. Nat Neurosci 11(12):1392-1401. doi:10.1038/nn. 2220

46. Robins SC, Trudel E, Rotondi O, Liu X, Djogo T, Kryzskaya D, Bourque CW, Kokoeva MV (2013) Evidence for NG2-glia derived, adult-born functional neurons in the hypothalamus. PLoS ONE 8(10):e78236. doi:10.1371/journal.pone.0078236

47. Guo F, Maeda Y, Ma J, Xu J, Horiuchi M, Miers L, Vaccarino F, Pleasure D (2010) Pyramidal neurons are generated from oligodendroglial progenitor cells in adult piriform cortex. J Neurosci Off J Soc Neurosci 30(36):12036-12049. doi:10.1523/ JNEUROSCI.1360-10.2010

48. Clarke LE, Young KM, Hamilton NB, Li H, Richardson WD, Attwell D (2012) Properties and fate of oligodendrocyte progenitor cells in the corpus callosum, motor cortex, and piriform cortex of the mouse. J Neurosci Off J Soc Neurosci 32(24):8173-8185. doi:10.1523/JNEUROSCI.0928-12.2012

49. Kang SH, Fukaya M, Yang JK, Rothstein JD, Bergles DE (2010) $\mathrm{NG} 2+\mathrm{CNS}$ glial progenitors remain committed to the oligodendrocyte lineage in postnatal life and following neurodegeneration. Neuron 68(4):668-681. doi:10.1016/j.neuron.2010.09.009

50. Zhu X, Hill RA, Dietrich D, Komitova M, Suzuki R, Nishiyama A (2011) Age-dependent fate and lineage restriction of single NG2 cells. Development 138(4):745-753. doi:10.1242/dev.047951

51. Ju P, Zhang S, Yeap Y, Feng Z (2012) Induction of neuronal phenotypes from $\mathrm{NG} 2+$ glial progenitors by inhibiting epidermal growth factor receptor in mouse spinal cord injury. Glia 60(11): 1801-1814. doi:10.1002/glia.22398

52. Heinrich C, Bergami M, Gascon S, Lepier A, Vigano F, Dimou L, Sutor B, Berninger B et al (2014) Sox2-mediated conversion of NG2 glia into induced neurons in the injured adult cerebral cortex. Stem Cell Rep. doi:10.1016/j.stemcr.2014.10.007

53. Sakry D, Neitz A, Singh J, Frischknecht R, Marongiu D, Biname F, Perera SS, Endres K et al (2014) Oligodendrocyte precursor cells modulate the neuronal network by activity-dependent ectodomain cleavage of glial NG2. PLoS Biol 12(11):e1001993. doi:10.1371/journal.pbio.1001993

54. Zalc B, Goujet D, Colman D (2008) The origin of the myelination program in vertebrates. Curr Biol CB 18(12):R511-512. doi:10. 1016/j.cub.2008.04.010

55. Hartline DK, Colman DR (2007) Rapid conduction and the evolution of giant axons and myelinated fibers. Curr Biol CB 17(1): R29-35. doi:10.1016/j.cub.2006.11.042

56. Bartzokis G, Sultzer D, Lu PH, Nuechterlein KH, Mintz J, Cummings JL (2004) Heterogeneous age-related breakdown of white matter structural integrity: implications for cortical "disconnection" in aging and Alzheimer's disease. Neurobiol Aging 25(7):843-851. doi:10.1016/j.neurobiolaging.2003.09.005

57. Schoenemann PT, Sheehan MJ, Glotzer LD (2005) Prefrontal white matter volume is disproportionately larger in humans than 
in other primates. Nat Neurosci 8(2):242-252. doi:10.1038/ nn1394

58. Smaers JB, Schleicher A, Zilles K, Vinicius L (2010) Frontal white matter volume is associated with brain enlargement and higher structural connectivity in anthropoid primates. PLoS ONE 5(2):e9123. doi:10.1371/journal.pone.0009123

59. Deoni SC, O'Muircheartaigh J, Elison JT, Walker L, Doernberg E, Waskiewicz N, Dirks H, Piryatinsky I et al (2014) White matter maturation profiles through early childhood predict general cognitive ability. Brain Struct Funct. doi:10.1007/s00429-014-0947-x

60. Hagmann P, Sporns O, Madan N, Cammoun L, Pienaar R, Wedeen VJ, Meuli R, Thiran JP et al (2010) White matter maturation reshapes structural connectivity in the late developing human brain. Proc Natl Acad Sci U S A 107(44):19067-19072. doi: 10.1073/pnas. 1009073107

61. Nagy Z, Westerberg H, Klingberg T (2004) Maturation of white matter is associated with the development of cognitive functions during childhood. J Cogn Neurosci 16(7):1227-1233. doi:10. 1162/0898929041920441

62. Hasegawa M, Houdou S, Mito T, Takashima S, Asanuma K, Ohno $\mathrm{T}$ (1992) Development of myelination in the human fetal and infant cerebrum: a myelin basic protein immunohistochemical study. Brain Dev 14(1):1-6

63. Miller DJ, Duka T, Stimpson CD, Schapiro SJ, Baze WB, McArthur MJ, Fobbs AJ, Sousa AM et al (2012) Prolonged myelination in human neocortical evolution. Proc Natl Acad Sci U S A 109(41):16480-16485. doi:10.1073/pnas.1117943109

64. Sakai T, Mikami A, Tomonaga M, Matsui M, Suzuki J, Hamada Y, Tanaka M, Miyabe-Nishiwaki T et al (2011) Differential prefrontal white matter development in chimpanzees and humans. Curr Biol CB 21(16):1397-1402. doi:10.1016/j.cub.2011.07.019

65. Bartzokis G, Beckson M, Lu PH, Nuechterlein KH, Edwards N, Mintz J (2001) Age-related changes in frontal and temporal lobe volumes in men: a magnetic resonance imaging study. Arch Gen Psychiatry 58(5):461-465

66. Bankston AN, Mandler MD, Feng Y (2013) Oligodendroglia and neurotrophic factors in neurodegeneration. Neurosci Bull 29(2): 216-228. doi:10.1007/s12264-013-1321-3

67. De Stefano N, Matthews PM, Fu L, Narayanan S, Stanley J, Francis GS, Antel JP, Arnold DL (1998) Axonal damage correlates with disability in patients with relapsing-remitting multiple sclerosis. Results of a longitudinal magnetic resonance spectroscopy study. Brain J Neurol 121(Pt 8):1469-1477

68. Fu L, Matthews PM, De Stefano N, Worsley KJ, Narayanan S, Francis GS, Antel JP, Wolfson C et al (1998) Imaging axonal damage of normal-appearing white matter in multiple sclerosis. Brain J Neurol 121(Pt 1):103-113

69. Trapp BD, Peterson J, Ransohoff RM, Rudick R, Mork S, Bo L (1998) Axonal transection in the lesions of multiple sclerosis. N Engl J Med 338(5):278-285. doi:10.1056/NEJM199801293380502

70. Wilkins A, Kondo Y, Song J, Liu S, Compston A, Black JA, Waxman SG, Duncan ID (2010) Slowly progressive axonal degeneration in a rat model of chronic, nonimmune-mediated demyelination. J Neuropathol Exp Neurol 69(12):1256-1269. doi:10. 1097/NEN.0b013e3181ffc317

71. Kornek B, Storch MK, Weissert R, Wallstroem E, Stefferl A, Olsson T, Linington C, Schmidbauer M et al (2000) Multiple sclerosis and chronic autoimmune encephalomyelitis: a comparative quantitative study of axonal injury in active, inactive, and remyelinated lesions. Am J Pathol 157(1):267-276. doi:10.1016/ S0002-9440(10)64537-3

72. Griffiths I, Klugmann M, Anderson T, Yool D, Thomson C, Schwab MH, Schneider A, Zimmermann F et al (1998) Axonal swellings and degeneration in mice lacking the major proteolipid of myelin. Science 280(5369):1610-1613
73. Nave KA (2010) Myelination and support of axonal integrity by glia. Nature 468(7321):244-252. doi:10.1038/nature09614

74. Kuhlmann T, Miron V, Cui Q, Wegner C, Antel J, Bruck W (2008) Differentiation block of oligodendroglial progenitor cells as a cause for remyelination failure in chronic multiple sclerosis. Brain J Neurol 131(Pt 7):1749-1758. doi:10.1093/brain/awn096

75. Chang A, Tourtellotte WW, Rudick R, Trapp BD (2002) Premyelinating oligodendrocytes in chronic lesions of multiple sclerosis. N Engl J Med 346(3):165-173. doi:10.1056/ NEJMoa010994

76. Seven A, Aslan M, Incir S, Altintas A (2013) Evaluation of oxidative and nitrosative stress in relapsing remitting multiple sclerosis: effect of corticosteroid therapy. Folia Neuropathol Assoc Pol Neuropathol Med Res Cent Pol Acad Sci 51(1):58-64

77. Bizzozero OA, DeJesus G, Bixler HA, Pastuszyn A (2005) Evidence of nitrosative damage in the brain white matter of patients with multiple sclerosis. Neurochem Res 30(1):139-149

78. Kremer D, Schichel T, Forster M, Tzekova N, Bernard C, van der Valk P, van Horssen J, Hartung HP et al (2013) Human endogenous retrovirus type $\mathrm{W}$ envelope protein inhibits oligodendroglial precursor cell differentiation. Ann Neurol 74(5):721-732. doi:10. 1002/ana.23970

79. Bossy-Wetzel E, Schwarzenbacher R, Lipton SA (2004) Molecular pathways to neurodegeneration. Nat Med 10(Suppl): S2-9. doi:10.1038/nm1067

80. Bartzokis G (2004) Age-related myelin breakdown: a developmental model of cognitive decline and Alzheimer's disease. Neurobiol Aging 25(1):5-18, author reply 49-62

81. Bartzokis G, Lu PH, Mintz J (2004) Quantifying age-related myelin breakdown with MRI: novel therapeutic targets for preventing cognitive decline and Alzheimer's disease. J Alzheimer's Dis JAD 6(6 Suppl):S53-59

82. Bartzokis G, Lu PH, Tishler TA, Fong SM, Oluwadara B, Finn JP, Huang D, Bordelon Y et al (2007) Myelin breakdown and iron changes in Huntington's disease: pathogenesis and treatment implications. Neurochem Res 32(10):1655-1664. doi:10.1007/ s11064-007-9352-7

83. Zakin MM, Baron B, Guillou F (2002) Regulation of the tissuespecific expression of transferrin gene. Dev Neurosci 24(2-3): 222-226

84. Puntarulo S (2005) Iron, oxidative stress and human health. Mol Asp Med 26(4-5):299-312. doi:10.1016/j.mam.2005.07.001

85. Grune T, Jung T, Merker K, Davies KJ (2004) Decreased proteolysis caused by protein aggregates, inclusion bodies, plaques, lipofuscin, ceroid, and 'aggresomes' during oxidative stress, aging, and disease. Int J Biochem Cell Biol 36(12):2519-2530. doi: 10.1016/j.biocel.2004.04.020

86. Bendlin BB, Carlsson CM, Johnson SC, Zetterberg H, Blennow K, Willette AA, Okonkwo OC, Sodhi A et al (2012) CSF T-Tau/ Abeta42 predicts white matter microstructure in healthy adults at risk for Alzheimer's disease. PLoS ONE 7(6):e37720. doi:10. 1371/journal.pone. 0037720

87. Back SA, Kroenke CD, Sherman LS, Lawrence G, Gong X, Taber EN, Sonnen JA, Larson EB et al (2011) White matter lesions defined by diffusion tensor imaging in older adults. Ann Neurol 70(3):465-476. doi:10.1002/ana.22484

88. Rosas HD, Tuch DS, Hevelone ND, Zaleta AK, Vangel M, Hersch SM, Salat DH (2006) Diffusion tensor imaging in presymptomatic and early Huntington's disease: selective white matter pathology and its relationship to clinical measures. Mov Disord Off J Mov Disord Soc 21(9):1317-1325. doi:10.1002/mds.20979

89. Mitew S, Kirkcaldie MT, Halliday GM, Shepherd CE, Vickers JC, Dickson TC (2010) Focal demyelination in Alzheimer's disease and transgenic mouse models. Acta Neuropathol 119(5):567-577. doi:10.1007/s00401-010-0657-2 
90. Schmued LC, Raymick J, Paule MG, Dumas M, Sarkar S (2013) Characterization of myelin pathology in the hippocampal complex of a transgenic mouse model of Alzheimer's disease. Curr Alzheimer Res 10(1):30-37

91. Behrendt G, Baer K, Buffo A, Curtis MA, Faull RL, Rees MI, Gotz M, Dimou L (2013) Dynamic changes in myelin aberrations and oligodendrocyte generation in chronic amyloidosis in mice and men. Glia 61(2):273-286. doi:10.1002/glia.22432

92. Desai MK, Mastrangelo MA, Ryan DA, Sudol KL, Narrow WC, Bowers WJ (2010) Early oligodendrocyte/myelin pathology in Alzheimer's disease mice constitutes a novel therapeutic target. Am J Pathol 177(3):1422-1435. doi:10.2353/ajpath.2010.100087

93. Horiuchi M, Maezawa I, Itoh A, Wakayama K, Jin LW, Itoh T, Decarli C (2012) Amyloid beta1-42 oligomer inhibits myelin sheet formation in vitro. Neurobiol Aging 33(3):499-509. doi: 10.1016/j.neurobiolaging.2010.05.007

94. Kang SH, Li Y, Fukaya M, Lorenzini I, Cleveland DW, Ostrow LW, Rothstein JD, Bergles DE (2013) Degeneration and impaired regeneration of gray matter oligodendrocytes in amyotrophic lateral sclerosis. Nat Neurosci 16(5):571-579. doi:10.1038/nn.3357

95. Philips T, Bento-Abreu A, Nonneman A, Haeck W, Staats K, Geelen V, Hersmus N, Kusters B et al (2013) Oligodendrocyte dysfunction in the pathogenesis of amyotrophic lateral sclerosis. Brain J Neurol 136(Pt 2):471-482. doi:10.1093/brain/aws339

96. Graham JG, Oppenheimer DR (1969) Orthostatic hypotension and nicotine sensitivity in a case of multiple system atrophy. $\mathrm{J}$ Neurol Neurosurg Psychiatry 32(1):28-34

97. Stefanova N, Bucke P, Duerr S, Wenning GK (2009) Multiple system atrophy: an update. Lancet Neurol 8(12):1172-1178. doi: 10.1016/S1474-4422(09)70288-1

98. Bower JH, Maraganore DM, McDonnell SK, Rocca WA (1997) Incidence of progressive supranuclear palsy and multiple system atrophy in Olmsted County, Minnesota, 1976 to 1990. Neurology 49(5): 1284-1288

99. Wenning GK, Colosimo C, Geser F, Poewe W (2004) Multiple system atrophy. Lancet Neurol 3(2):93-103

100. Wenning GK, Geser F, Krismer F, Seppi K, Duerr S, Boesch S, Kollensperger M, Goebel G et al (2013) The natural history of multiple system atrophy: a prospective European cohort study. Lancet Neurol 12(3):264-274. doi:10.1016/S1474-4422(12) 70327-7

101. Collaboration M-SAR (2013) Mutations in COQ2 in familial and sporadic multiple-system atrophy. N Engl J Med 369(3):233-244. doi:10.1056/NEJMoa1212115

102. Chen YP, Zhao B, Cao B, Song W, Guo X, Wei QQ, Yang Y, Yuan LX et al (2014) Mutation scanning of the COQ2 gene in ethnic Chinese patients with multiple-system atrophy. Neurobiol Aging. doi:10.1016/j.neurobiolaging.2014.09.010

103. Ogaki K, Fujioka S, Heckman MG, Rayaprolu S, Soto-Ortolaza AI, Labbe C, Walton RL, Lorenzo-Betancor O et al (2014) Analysis of COQ2 gene in multiple system atrophy. Mol Neurodegener 9:44. doi:10.1186/1750-1326-9-44

104. Ozawa T, Paviour D, Quinn NP, Josephs KA, Sangha H, Kilford L, Healy DG, Wood NW et al (2004) The spectrum of pathological involvement of the striatonigral and olivopontocerebellar systems in multiple system atrophy: clinicopathological correlations. Brain J Neurol 127(Pt 12):2657-2671. doi:10.1093/brain/awh303

105. Wenning GK, Tison F, Ben Shlomo Y, Daniel SE, Quinn NP (1997) Multiple system atrophy: a review of 203 pathologically proven cases. Mov Disord Off J Mov Disord Soc 12(2):133-147. doi: $10.1002 / \mathrm{mds} .870120203$

106. Ozawa T (2007) Morphological substrate of autonomic failure and neurohormonal dysfunction in multiple system atrophy: impact on determining phenotype spectrum. Acta Neuropathol 114(3):201211. doi:10.1007/s00401-007-0254-1
107. Matsuo A, Akiguchi I, Lee GC, McGeer EG, McGeer PL, Kimura J (1998) Myelin degeneration in multiple system atrophy detected by unique antibodies. Am J Pathol 153(3):735-744. doi:10.1016/ S0002-9440(10)65617-9

108. Papp MI, Kahn JE, Lantos PL (1989) Glial cytoplasmic inclusions in the CNS of patients with multiple system atrophy (striatonigral degeneration, olivopontocerebellar atrophy and Shy-Drager syndrome). J Neurol Sci 94(1-3):79-100

109. Song YJ, Lundvig DM, Huang Y, Gai WP, Blumbergs PC, Hojrup P, Otzen D, Halliday GM et al (2007) p25alpha relocalizes in oligodendroglia from myelin to cytoplasmic inclusions in multiple system atrophy. Am J Pathol 171(4):1291-1303. doi:10.2353/ ajpath.2007.070201

110. Brooks DJ, Seppi K, Neuroimaging Working Group on MSA (2009) Proposed neuroimaging criteria for the diagnosis of multiple system atrophy. Mov Disord Off J Mov Disord Soc 24(7):949 964. doi:10.1002/mds.22413

111. Prodoehl J, Li H, Planetta PJ, Goetz CG, Shannon KM, Tangonan R, Comella CL, Simuni T et al (2013) Diffusion tensor imaging of Parkinson's disease, atypical parkinsonism, and essential tremor. Mov Disord Off J Mov Disord Soc 28(13):1816-1822. doi:10. $1002 /$ mds. 25491

112. Blain CR, Barker GJ, Jarosz JM, Coyle NA, Landau S, Brown RG, Chaudhuri KR, Simmons A et al (2006) Measuring brain stem and cerebellar damage in parkinsonian syndromes using diffusion tensor MRI. Neurology 67(12):2199-2205. doi:10.1212/ 01.wnl.0000249307.59950.f8

113. Paviour DC, Thornton JS, Lees AJ, Jager HR (2007) Diffusionweighted magnetic resonance imaging differentiates Parkinsonian variant of multiple-system atrophy from progressive supranuclear palsy. Mov Disord Off J Mov Disord Soc 22(1):68-74. doi:10. 1002/mds. 21204

114. Schocke MF, Seppi K, Esterhammer R, Kremser C, Jaschke W, Poewe W, Wenning GK (2002) Diffusion-weighted MRI differentiates the Parkinson variant of multiple system atrophy from PD. Neurology 58(4):575-580

115. Shiga K, Yamada K, Yoshikawa K, Mizuno T, Nishimura T, Nakagawa M (2005) Local tissue anisotropy decreases in cerebellopetal fibers and pyramidal tract in multiple system atrophy. J Neurol 252(5):589-596. doi:10.1007/s00415-005-0708-0

116. Ubhi K, Low P, Masliah E (2011) Multiple system atrophy: a clinical and neuropathological perspective. Trends Neurosci 34(11):581-590. doi:10.1016/j.tins.2011.08.003

117. Salvesen L, Ullerup BH, Sunay FB, Brudek T, Lokkegaard A, Agander TK, Winge K, Pakkenberg B (2014) Changes in total cell numbers of the basal ganglia in patients with multiple system atrophy-a stereological study. Neurobiol Dis 74C:104-113. doi:10.1016/j.nbd.2014.11.008

118. Ishizawa K, Komori T, Arai N, Mizutani T, Hirose T (2008) Glial cytoplasmic inclusions and tissue injury in multiple system atrophy: a quantitative study in white matter (olivopontocerebellar system) and gray matter (nigrostriatal system). Neuropathol Off $\mathrm{J}$ Jpn Soc Neuropathol 28(3):249-257. doi:10.1111/j.1440-1789. 2007.00855.x

119. Song YJ, Halliday GM, Holton JL, Lashley T, O'Sullivan SS, McCann H, Lees AJ, Ozawa T et al (2009) Degeneration in different parkinsonian syndromes relates to astrocyte type and astrocyte protein expression. J Neuropathol Exp Neurol 68(10):10731083. doi:10.1097/NEN.0b013e3181b66flb

120. Ishizawa K, Komori T, Sasaki S, Arai N, Mizutani T, Hirose T (2004) Microglial activation parallels system degeneration in multiple system atrophy. J Neuropathol Exp Neurol 63(1):43-52

121. Papp MI, Lantos PL (1992) Accumulation of tubular structures in oligodendroglial and neuronal cells as the basic alteration in multiple system atrophy. J Neurol Sci 107(2):172-182 
122. Papp MI, Lantos PL (1994) The distribution of oligodendroglial inclusions in multiple system atrophy and its relevance to clinical symptomatology. Brain J Neurol 117(Pt 2):235-243

123. Lantos PL, Papp MI (1994) Cellular pathology of multiple system atrophy: a review. J Neurol Neurosurg Psychiatry 57(2):129-133

124. Halliday GM, Holton JL, Revesz T, Dickson DW (2011) Neuropathology underlying clinical variability in patients with synucleinopathies. Acta Neuropathol 122(2):187-204. doi:10. 1007/s00401-011-0852-9

125. Inoue M, Yagishita S, Ryo M, Hasegawa K, Amano N, Matsushita M (1997) The distribution and dynamic density of oligodendroglial cytoplasmic inclusions (GCIs) in multiple system atrophy: a correlation between the density of GCIs and the degree of involvement of striatonigral and olivopontocerebellar systems. Acta Neuropathol 93(6):585-591

126. Spillantini MG, Crowther RA, Jakes R, Cairns NJ, Lantos PL, Goedert M (1998) Filamentous alpha-synuclein inclusions link multiple system atrophy with Parkinson's disease and dementia with Lewy bodies. Neurosci Lett 251(3):205-208

127. Tu PH, Galvin JE, Baba M, Giasson B, Tomita T, Leight S, Nakajo S, Iwatsubo T et al (1998) Glial cytoplasmic inclusions in white matter oligodendrocytes of multiple system atrophy brains contain insoluble alpha-synuclein. Ann Neurol 44(3):415-422. doi:10. 1002/ana.410440324

128. Wakabayashi K, Yoshimoto M, Tsuji S, Takahashi H (1998) Alpha-synuclein immunoreactivity in glial cytoplasmic inclusions in multiple system atrophy. Neurosci Lett 249(2-3):180-182

129. McCann H, Stevens CH, Cartwright H, Halliday GM (2014) alpha-Synucleinopathy phenotypes. Parkinsonism Relat Disord 20(Suppl 1):S62-67. doi:10.1016/S1353-8020(13)70017-8

130. Nakamura S, Kawamoto Y, Nakano S, Akiguchi I, Kimura J (1998) Cyclin-dependent kinase 5 and mitogen-activated protein kinase in glial cytoplasmic inclusions in multiple system atrophy. J Neuropathol Exp Neurol 57(7):690-698

131. Kato S, Shinozawa T, Takikawa M, Kato M, Hirano A, Awaya A, Ohama E (2000) Midkine, a new neurotrophic factor, is present in glial cytoplasmic inclusions of multiple system atrophy brains. Acta Neuropathol 100(5):481-489

132. Nakamura S, Kawamoto Y, Nakano S, Akiguchi I (2000) Expression of the endocytosis regulatory proteins Rab5 and Rabaptin-5 in glial cytoplasmic inclusions from brains with multiple system atrophy. Clin Neuropathol 19(2):51-56

133. Honjyo Y, Kawamoto Y, Nakamura S, Nakano S, Akiguchi I (2001) P39 immunoreactivity in glial cytoplasmic inclusions in brains with multiple system atrophy. Acta Neuropathol 101(3): 190-194

134. Iwata A, Miura S, Kanazawa I, Sawada M, Nukina N (2001) alpha-Synuclein forms a complex with transcription factor Elk-1. J Neurochem 77(1):239-252

135. Piao YS, Hayashi S, Hasegawa M, Wakabayashi K, Yamada M, Yoshimoto M, Ishikawa A, Iwatsubo T et al (2001) Colocalization of alpha-synuclein and phosphorylated tau in neuronal and glial cytoplasmic inclusions in a patient with multiple system atrophy of long duration. Acta Neuropathol 101(3):285-293

136. Kawamoto Y, Akiguchi I, Nakamura S, Budka H (2002) Accumulation of 14-3-3 proteins in glial cytoplasmic inclusions in multiple system atrophy. Ann Neurol 52(6):722-731. doi:10. 1002/ana.10361

137. Sasaki K, Doh-ura K, Wakisaka Y, Iwaki T (2002) Clusterin/ apolipoprotein $\mathrm{J}$ is associated with cortical Lewy bodies: immunohistochemical study in cases with alpha-synucleinopathies. Acta Neuropathol 104(3):225-230. doi:10.1007/s00401-0020546-4

138. Wakabayashi K, Engelender S, Tanaka Y, Yoshimoto M, Mori F, Tsuji S, Ross CA, Takahashi H (2002) Immunocytochemical localization of synphilin-1, an alpha-synuclein-associated protein, in neurodegenerative disorders. Acta Neuropathol 103(3):209-214. doi:10.1007/s004010100451

139. Hishikawa N, Niwa J, Doyu M, Ito T, Ishigaki S, Hashizume Y, Sobue G (2003) Dorfin localizes to the ubiquitylated inclusions in Parkinson's disease, dementia with Lewy bodies, multiple system atrophy, and amyotrophic lateral sclerosis. Am J Pathol 163(2): 609-619

140. Pountney DL, Chegini F, Shen X, Blumbergs PC, Gai WP (2005) SUMO-1 marks subdomains within glial cytoplasmic inclusions of multiple system atrophy. Neurosci Lett 381(1-2):74-79. doi:10. 1016/j.neulet.2005.02.013

141. Pountney DL, Treweek TM, Chataway T, Huang Y, Chegini F, Blumbergs PC, Raftery MJ, Gai WP (2005) Alpha B-crystallin is a major component of glial cytoplasmic inclusions in multiple system atrophy. Neurotox Res 7(1-2):77-85

142. Tanji K, Mori F, Kakita A, Zhang H, Kito K, Kamitani T, Takahashi H, Wakabayashi K (2007) Immunohistochemical localization of NUB1, a synphilin-1-binding protein, in neurodegenerative disorders. Acta Neuropathol 114(4):365-371. doi:10.1007/ s00401-007-0238-1

143. Taylor JM, Song YJ, Huang Y, Farrer MJ, Delatycki MB, Halliday GM, Lockhart PJ (2007) Parkin Co-Regulated Gene (PACRG) is regulated by the ubiquitin-proteasomal system and is present in the pathological features of Parkinsonian diseases. Neurobiol Dis 27(2):238-247. doi:10.1016/j.nbd.2007.04.014

144. Honjo Y, Shirakashi Y, Kawamoto Y, Akiguchi I (2008) AntiDARPP32 antibody-immunopositive inclusions in the brain of patients with multiple system atrophy. Clin Neuropathol 27(5): 309-316

145. Kawamoto Y, Kobayashi Y, Suzuki Y, Inoue H, Tomimoto H, Akiguchi I, Budka H, Martins LM et al (2008) Accumulation of HtrA2/Omi in neuronal and glial inclusions in brains with alphasynucleinopathies. J Neuropathol Exp Neurol 67(10):984-993. doi:10.1097/NEN.0b013e31818809f4

146. Honjo Y, Ito H, Horibe T, Takahashi R, Kawakami K (2011) Protein disulfide isomerase immunopositive glial cytoplasmic inclusions in patients with multiple system atrophy. Int J Neurosci 121(10):543-550. doi:10.3109/00207454.2011.585440

147. Pountney DL, Dickson TC, Power JH, Vickers JC, West AJ, Gai WP (2011) Association of metallothionein-III with oligodendroglial cytoplasmic inclusions in multiple system atrophy. Neurotox Res 19(1):115-122. doi:10.1007/s12640-009-9146-6

148. Chiba Y, Takei S, Kawamura N, Kawaguchi Y, Sasaki K, Hasegawa-Ishii S, Furukawa A, Hosokawa M et al (2012) Immunohistochemical localization of aggresomal proteins in glial cytoplasmic inclusions in multiple system atrophy. Neuropathol Appl Neurobiol 38(6):559-571. doi:10.1111/j.1365-2990.2011. 01229.x

149. Odagiri S, Tanji K, Mori F, Kakita A, Takahashi H, Wakabayashi K (2012) Autophagic adapter protein NBR1 is localized in Lewy bodies and glial cytoplasmic inclusions and is involved in aggregate formation in alpha-synucleinopathy. Acta Neuropathol 124(2):173-186. doi:10.1007/s00401-012-0975-7

150. Zhao T, Severijnen LA, van der Weiden M, Zheng PP, Oostra BA, Hukema RK, Willemsen R, Kros JM et al (2013) FBXO7 immunoreactivity in alpha-synuclein-containing inclusions in Parkinson disease and multiple system atrophy. J Neuropathol Exp Neurol 72(6):482-488. doi:10.1097/NEN.0b013e318293c586

151. Kawamoto Y, Ito H, Ihara M, Takahashi R (2014) XIAP immunoreactivity in glial and neuronal cytoplasmic inclusions in multiple system atrophy. Clin Neuropathol 33(1):76-83. doi:10.5414/ NP300610

152. Gai WP, Pountney DL, Power JH, Li QX, Culvenor JG, McLean CA, Jensen PH, Blumbergs PC (2003) alpha-Synuclein fibrils constitute the central core of oligodendroglial inclusion filaments in multiple system atrophy. Exp Neurol 181(1):68-78 
153. Lindersson E, Lundvig D, Petersen C, Madsen P, Nyengaard JR, Hojrup P, Moos T, Otzen D et al (2005) p25alpha Stimulates alpha-synuclein aggregation and is co-localized with aggregated alpha-synuclein in alpha-synucleinopathies. J Biol Chem 280(7): 5703-5715. doi:10.1074/jbc.M410409200

154. Kovacs GG, Gelpi E, Lehotzky A, Hoftberger R, Erdei A, Budka $\mathrm{H}$, Ovadi J (2007) The brain-specific protein TPPP/p25 in pathological protein deposits of neurodegenerative diseases. Acta Neuropathol 113(2):153-161. doi:10.1007/s00401-006-0167-4

155. Don AS, Hsiao JH, Bleasel JM, Couttas TA, Halliday GM, Kim W (2014) Altered lipid levels provide evidence for myelin dysfunction in multiple system atrophy. Acta Neuropathol Commun 2(1): 150. doi:10.1186/s40478-014-0150-6

156. Bleasel JM, Hsiao JH, Halliday GM, Kim WS (2013) Increased expression of ABCA8 in multiple system atrophy brain is associated with changes in pathogenic proteins. J Park Dis 3(3):331339. doi:10.3233/JPD-130203

157. Makioka K, Yamazaki T, Fujita Y, Takatama M, Nakazato Y, Okamoto K (2010) Involvement of endoplasmic reticulum stress defined by activated unfolded protein response in multiple system atrophy. J Neurol Sci 297(1-2):60-65. doi:10.1016/j.jns.2010.06. 019

158. Uyama N, Uchihara T, Mochizuki Y, Nakamura A, Takahashi R, Mizutani T (2009) Selective nuclear shrinkage of oligodendrocytes lacking glial cytoplasmic inclusions in multiple system atrophy: a 3-dimensional volumetric study. J Neuropathol Exp Neurol 68(10):1084-1091. doi:10.1097/NEN.0b013e3181b67678

159. Duda JE, Giasson BI, Gur TL, Montine TJ, Robertson D, Biaggioni I, Hurtig HI, Stern MB et al (2000) Immunohistochemical and biochemical studies demonstrate a distinct profile of alpha-synuclein permutations in multiple system atrophy. J Neuropathol Exp Neurol 59(9):830-841

160. Dickson DW, Liu W, Hardy J, Farrer M, Mehta N, Uitti R, Mark M, Zimmerman T et al (1999) Widespread alterations of alphasynuclein in multiple system atrophy. Am J Pathol 155(4):12411251

161. Campbell BC, McLean CA, Culvenor JG, Gai WP, Blumbergs PC, Jakala P, Beyreuther K, Masters CL et al (2001) The solubility of alpha-synuclein in multiple system atrophy differs from that of dementia with Lewy bodies and Parkinson's disease. J Neurochem 76(1):87-96

162. Pountney DL, Lowe R, Quilty M, Vickers JC, Voelcker NH, Gai WP (2004) Annular alpha-synuclein species from purified multiple system atrophy inclusions. J Neurochem 90(2):502-512. doi: 10.1111/j.1471-4159.2004.02533.x

163. Giasson BI, Duda JE, Murray IV, Chen Q, Souza JM, Hurtig HI, Ischiropoulos H, Trojanowski JQ et al (2000) Oxidative damage linked to neurodegeneration by selective alpha-synuclein nitration in synucleinopathy lesions. Science 290(5493):985-989

164. Jin $\mathrm{H}$, Ishikawa $\mathrm{K}$, Tsunemi $\mathrm{T}$, Ishiguro T, Amino T, Mizusawa $\mathrm{H}$ (2008) Analyses of copy number and mRNA expression level of the alpha-synuclein gene in multiple system atrophy. J Med Dent Sci 55(1):145-153

165. Miller DW, Johnson JM, Solano SM, Hollingsworth ZR, Standaert DG, Young AB (2005) Absence of alpha-synuclein mRNA expression in normal and multiple system atrophy oligodendroglia. J Neural Transm 112(12):1613-1624. doi:10.1007/ s00702-005-0378-1

166. Asi YT, Simpson JE, Heath PR, Wharton SB, Lees AJ, Revesz T, Houlden H, Holton JL (2014) Alpha-synuclein mRNA expression in oligodendrocytes in MSA. Glia 62(6):964-970. doi:10.1002/ glia. 22653

167. Solano SM, Miller DW, Augood SJ, Young AB, Penney JB Jr (2000) Expression of alpha-synuclein, parkin, and ubiquitin carboxy-terminal hydrolase L1 mRNA in human brain: genes associated with familial Parkinson's disease. Ann Neurol 47(2): 201-210

168. Ozawa T, Okuizumi K, Ikeuchi T, Wakabayashi K, Takahashi H, Tsuji S (2001) Analysis of the expression level of alpha-synuclein mRNA using postmortem brain samples from pathologically confirmed cases of multiple system atrophy. Acta Neuropathol 102(2):188-190

169. Lincoln SJ, Ross OA, Milkovic NM, Dickson DW, Rajput A, Robinson CA, Papapetropoulos S, Mash DC et al (2007) Quantitative PCR-based screening of alpha-synuclein multiplication in multiple system atrophy. Parkinsonism Relat Disord 13(6): 340-342. doi:10.1016/j.parkreldis.2006.12.005

170. Ozawa T, Healy DG, Abou-Sleiman PM, Ahmadi KR, Quinn N, Lees AJ, Shaw K, Wullner U et al (2006) The alpha-synuclein gene in multiple system atrophy. J Neurol Neurosurg Psychiatry 77(4):464-467. doi:10.1136/jnnp.2005.073528

171. Ozawa T, Takano H, Onodera O, Kobayashi H, Ikeuchi T, Koide R, Okuizumi K, Shimohata Tet al (1999) No mutation in the entire coding region of the alpha-synuclein gene in pathologically confirmed cases of multiple system atrophy. Neurosci Lett 270(2): $110-112$

172. Scholz SW, Houlden H, Schulte C, Sharma M, Li A, Berg D, Melchers A, Paudel R et al (2009) SNCA variants are associated with increased risk for multiple system atrophy. Ann Neurol 65(5): 610-614. doi:10.1002/ana.21685

173. Al-Chalabi A, Durr A, Wood NW, Parkinson MH, Camuzat A, Hulot JS, Morrison KE, Renton A et al (2009) Genetic variants of the alpha-synuclein gene SNCA are associated with multiple system atrophy. PLoS ONE 4(9):e7114. doi:10.1371/journal.pone. 0007114

174. Ettle B, Reiprich S, Deusser J, Schlachetzki JC, Xiang W, Prots I, Masliah E, Winner B et al (2014) Intracellular alpha-synuclein affects early maturation of primary oligodendrocyte progenitor cells. Mol Cell Neurosci 62:68-78. doi:10.1016/j.mcn.2014.06. 012

175. Rockenstein E, Ubhi K, Inglis C, Mante M, Patrick C, Adame A, Masliah E (2012) Neuronal to oligodendroglial alpha-synuclein redistribution in a double transgenic model of multiple system atrophy. Neuroreport 23(4):259-264. doi:10.1097/WNR. 0b013e3283509842

176. Reyes JF, Rey NL, Bousset L, Melki R, Brundin P, Angot E (2014) Alpha-synuclein transfers from neurons to oligodendrocytes. Glia 62(3):387-398. doi:10.1002/glia.22611

177. Kisos H, Ben-Gedalya T, Sharon R (2013) The clathrin-dependent localization of dopamine transporter to surface membranes is affected by alpha-synuclein. J Mol Neurosci MN. doi:10.1007/ s12031-013-0118-1

178. Kisos H, Pukass K, Ben-Hur T, Richter-Landsberg C, Sharon R (2012) Increased neuronal alpha-synuclein pathology associates with its accumulation in oligodendrocytes in mice modeling alpha-synucleinopathies. PLoS ONE 7(10):e46817. doi:10.1371/ journal.pone.0046817

179. Tsuboi K, Grzesiak JJ, Bouvet M, Hashimoto M, Masliah E, Shults CW (2005) Alpha-synuclein overexpression in oligodendrocytic cells results in impaired adhesion to fibronectin and cell death. Mol Cell Neurosci 29(2):259-268. doi:10.1016/j. men.2005.03.001

180. Richter-Landsberg C, Gorath M, Trojanowski JQ, Lee VM (2000) alpha-synuclein is developmentally expressed in cultured rat brain oligodendrocytes. J Neurosci Res 62(1):9-14

181. Konno M, Hasegawa T, Baba T, Miura E, Sugeno N, Kikuchi A, Fiesel FC, Sasaki T et al (2012) Suppression of dynamin GTPase decreases alpha-synuclein uptake by neuronal and oligodendroglial cells: a potent therapeutic target for synucleinopathy. Mol Neurodegener 7:38. doi:10.1186/1750-1326-7-38 
182. Ahmed Z, Asi YT, Lees AJ, Revesz T, Holton JL (2013) Identification and quantification of oligodendrocyte precursor cells in multiple system atrophy, progressive supranuclear palsy and Parkinson's disease. Brain Pathol 23(3):263-273. doi:10. 1111/j.1750-3639.2012.00637.x

183. May VE, Ettle B, Poehler AM, Nuber S, Ubhi K, Rockenstein E, Winner B, Wegner M et al (2014) alpha-Synuclein impairs oligodendrocyte progenitor maturation in multiple system atrophy. Neurobiol Aging 35(10):2357-2368. doi:10.1016/j. neurobiolaging.2014.02.028

184. Yazawa I, Giasson BI, Sasaki R, Zhang B, Joyce S, Uryu K, Trojanowski JQ, Lee VM (2005) Mouse model of multiple system atrophy alpha-synuclein expression in oligodendrocytes causes glial and neuronal degeneration. Neuron 45(6):847-859. doi:10. 1016/j.neuron.2005.01.032

185. Kahle PJ, Neumann M, Ozmen L, Muller V, Jacobsen H, Spooren W, Fuss B, Mallon B et al (2002) Hyperphosphorylation and insolubility of alpha-synuclein in transgenic mouse oligodendrocytes. EMBO Rep 3(6):583-588. doi:10.1093/embo-reports/ kvf109

186. Shults CW, Rockenstein E, Crews L, Adame A, Mante M, Larrea G, Hashimoto M, Song D et al (2005) Neurological and neurodegenerative alterations in a transgenic mouse model expressing human alpha-synuclein under oligodendrocyte promoter: implications for multiple system atrophy. J Neurosci Off J Soc Neurosci 25(46):10689-10699. doi:10.1523/JNEUROSCI.3527-05.2005

187. Ubhi K, Lee PH, Adame A, Inglis C, Mante M, Rockenstein E, Stefanova N, Wenning GK et al (2009) Mitochondrial inhibitor 3nitroproprionic acid enhances oxidative modification of alphasynuclein in a transgenic mouse model of multiple system atrophy. J Neurosci Res 87(12):2728-2739. doi:10.1002/jnr.22089

188. Krismer F, Wenning GK, Li Y, Poewe W, Stefanova N (2013) Intact olfaction in a mouse model of multiple system atrophy. PLoS ONE 8(5):e64625. doi:10.1371/journal.pone.0064625

189. Kuzdas D, Stemberger S, Gaburro S, Stefanova N, Singewald N, Wenning GK (2013) Oligodendroglial alpha-synucleinopathy and MSA-like cardiovascular autonomic failure: experimental evidence. Exp Neurol 247:531-536. doi:10.1016/j.expneurol.2013. 02.002

190. Tank J, da Costa-Goncalves AC, Kamer I, Qadri F, Ubhi K, Rockenstein E, Diedrich A, Masliah E, Gross V, Jordan J (2014) Preserved functional autonomic phenotype in adult mice overexpressing moderate levels of human alpha-synuclein in oligodendrocytes. Physiol. Rep. 2 (11). doi:10.14814/phy2.12209

191. Boudes M, Uvin P, Pinto S, Voets T, Fowler CJ, Wenning GK, De Ridder D, Stefanova N (2013) Bladder dysfunction in a transgenic mouse model of multiple system atrophy. Mov Disord Off J Mov Disord Soc 28(3):347-355. doi:10.1002/mds.25336

192. Flabeau O, Meissner WG, Ozier A, Berger P, Tison F, Fernagut PO (2014) Breathing variability and brainstem serotonergic loss in a genetic model of multiple system atrophy. Mov Disord Off $\mathbf{J}$ Mov Disord Soc 29(3):388-395. doi:10.1002/mds.25804

193. Stemberger S, Poewe W, Wenning GK, Stefanova N (2010) Targeted overexpression of human alpha-synuclein in oligodendroglia induces lesions linked to MSA-like progressive autonomic failure. Exp Neurol 224(2):459-464. doi:10.1016/j.expneurol. 2010.05.008

194. Suzuki Y, Jin C, Yazawa I (2014) Cystatin C triggers neuronal degeneration in a model of multiple system atrophy. Am J Pathol 184(3):790-799. doi:10.1016/j.ajpath.2013.11.018

195. Stefanova N, Kaufmann WA, Humpel C, Poewe W, Wenning GK (2012) Systemic proteasome inhibition triggers neurodegeneration in a transgenic mouse model expressing human alpha-synuclein under oligodendrocyte promoter: implications for multiple system atrophy. Acta Neuropathol 124(1):51-65. doi:10.1007/s00401012-0977-5
196. Schwarz L, Goldbaum O, Bergmann M, Probst-Cousin S, RichterLandsberg C (2012) Involvement of macroautophagy in multiple system atrophy and protein aggregate formation in oligodendrocytes. J Mol Neurosci MN 47(2):256-266. doi:10.1007/s12031012-9733-5

197. Stefanova N, Reindl M, Neumann M, Haass C, Poewe W, Kahle PJ, Wenning GK (2005) Oxidative stress in transgenic mice with oligodendroglial alpha-synuclein overexpression replicates the characteristic neuropathology of multiple system atrophy. Am J Pathol 166(3):869-876

198. Pukass K, Richter-Landsberg C (2014) Oxidative stress promotes uptake, accumulation, and oligomerization of extracellular alphasynuclein in oligodendrocytes. J Mol Neurosci MN 52(3):339352. doi:10.1007/s12031-013-0154-x

199. Riedel M, Goldbaum O, Wille M, Richter-Landsberg C (2011) Membrane lipid modification by docosahexaenoic acid (DHA) promotes the formation of alpha-synuclein inclusion bodies immunopositive for SUMO-1 in oligodendroglial cells after oxidative stress. J Mol Neurosci MN 43(3):290-302. doi:10.1007/ s12031-010-9439-5

200. Brand A, Bauer NG, Hallott A, Goldbaum O, Ghebremeskel K, Reifen R, Richter-Landsberg C (2010) Membrane lipid modification by polyunsaturated fatty acids sensitizes oligodendroglial OLN-93 cells against oxidative stress and promotes upregulation of heme oxygenase-1 (HSP32). J Neurochem 113(2): 465-476. doi:10.1111/j.1471-4159.2010.06611.x

201. Riedel M, Goldbaum O, Richter-Landsberg C (2009) alphaSynuclein promotes the recruitment of tau to protein inclusions in oligodendroglial cells: effects of oxidative and proteolytic stress. J Mol Neurosci MN 39(1-2):226-234. doi:10.1007/ s12031-009-9190-y

202. Kragh CL, Fillon G, Gysbers A, Hansen HD, Neumann M, Richter-Landsberg C, Haass C, Zalc B et al (2013) FASdependent cell death in alpha-synuclein transgenic oligodendrocyte models of multiple system atrophy. PLoS ONE 8(1):e55243. doi:10.1371/journal.pone.0055243

203. Kragh CL, Lund LB, Febbraro F, Hansen HD, Gai WP, El-Agnaf O, Richter-Landsberg C, Jensen PH (2009) Alpha-synuclein aggregation and Ser-129 phosphorylation-dependent cell death in oligodendroglial cells. J Biol Chem 284(15):10211-10222. doi: 10.1074/jbc.M809671200

204. Stefanova N, Georgievska B, Eriksson H, Poewe W, Wenning GK (2012) Myeloperoxidase inhibition ameliorates multiple system atrophy-like degeneration in a transgenic mouse model. Neurotox Res 21(4):393-404. doi:10.1007/s12640-011-9294-3

205. Stefanova N, Puschban Z, Fernagut PO, Brouillet E, Tison F, Reindl M, Jellinger KA, Poewe W et al (2003) Neuropathological and behavioral changes induced by various treatment paradigms with MPTP and 3-nitropropionic acid in mice: towards a model of striatonigral degeneration (multiple system atrophy). Acta Neuropathol 106(2):157-166. doi:10.1007/ s00401-003-0717-y

206. Ubhi K, Rockenstein E, Mante M, Inglis C, Adame A, Patrick C, Masliah E (2010) Alpha-synuclein deficient mice are resistant to toxin-induced multiple system atrophy. Neuroreport 21(6):457462. doi:10.1097/WNR.0b013e328338ba6b

207. Pfeiffer SE, Warrington AE, Bansal R (1993) The oligodendrocyte and its many cellular processes. Trends Cell Biol 3(6):191-197

208. Ubhi K, Rockenstein E, Mante M, Inglis C, Adame A, Patrick C, Whitney K, Masliah E (2010) Neurodegeneration in a transgenic mouse model of multiple system atrophy is associated with altered expression of oligodendroglial-derived neurotrophic factors. J Neurosci Off J Soc Neurosci 30(18):6236-6246. doi:10.1523/ JNEUROSCI.0567-10.2010 
209. Ubhi K, Inglis C, Mante M, Patrick C, Adame A, Spencer B, Rockenstein E, May V et al (2012) Fluoxetine ameliorates behavioral and neuropathological deficits in a transgenic model mouse of alpha-synucleinopathy. Exp Neurol 234(2):405-416. doi:10. 1016/j.expneurol.2012.01.008

210. Wenning GK, Stefanova N, Jellinger KA, Poewe W, Schlossmacher MG (2008) Multiple system atrophy: a primary oligodendrogliopathy. Ann Neurol 64(3):239-246. doi:10.1002/ ana. 21465

211. Schwarz J, Weis S, Kraft E, Tatsch K, Bandmann O, Mehraein P, Vogl T, Oertel WH (1996) Signal changes on MRI and increases in reactive microgliosis, astrogliosis, and iron in the putamen of two patients with multiple system atrophy. J Neurol Neurosurg Psychiatry 60(1):98-101

212. Stefanova N, Reindl M, Neumann M, Kahle PJ, Poewe W, Wenning GK (2007) Microglial activation mediates neurodegeneration related to oligodendroglial alpha-synucleinopathy: implications for multiple system atrophy. Mov Disord Off J Mov Disord Soc 22(15):2196-2203. doi:10.1002/mds.21671

213. Fellner L, Irschick R, Schanda K, Reindl M, Klimaschewski L, Poewe W, Wenning GK, Stefanova N (2013) Toll-like receptor 4 is required for alpha-synuclein dependent activation of microglia and astroglia. Glia 61(3):349-360. doi:10.1002/ glia. 22437 